\title{
REVIEW
}

\section{Climate change and aquaculture: considering adaptation potential}

\author{
Gregor K. Reid ${ }^{1,2, *}$, Helen J. Gurney-Smith ${ }^{1,3}$, Mark Flaherty ${ }^{4}$, Amber F. Garber ${ }^{5}$, \\ Ian Forster ${ }^{6}$, Kathy Brewer-Dalton ${ }^{7}$, Duncan Knowler ${ }^{8}$, David J. Marcogliese ${ }^{1,9}$, \\ Thierry Chopin ${ }^{2,10}$, Richard D. Mocciaa ${ }^{11}$, Caitlin T. Smith ${ }^{12}$, Sena De Silva ${ }^{13}$ \\ ${ }^{1}$ St. Andrews Biological Station, Fisheries and Oceans Canada, St. Andrews, NB E5B 0E4, Canada \\ ${ }^{2}$ Canadian Integrated Multi-Trophic Aquaculture Network (CIMTAN), University of New Brunswick, \\ Saint John, NB E2L 4L5, Canada \\ ${ }^{3}$ Department of Biology, University of Victoria, Victoria, BC V8P 5C2, Canada \\ ${ }^{4}$ Department of Geography, University of Victoria, Victoria, BC V8P 5C2, Canada \\ ${ }^{5}$ Huntsman Marine Science Centre, St. Andrews, NB E5B 2L7, Canada \\ ${ }^{6}$ Pacific Science Enterprise Centre, Fisheries and Oceans Canada, West Vancouver, BC V7V 1N6, Canada \\ ${ }^{7}$ New Brunswick Department of Agriculture, Aquaculture and Fisheries, Fredericton, NB E3B 5H1, Canada \\ ${ }^{8}$ School of Resource and Environmental Management, Simon Fraser University, Burnaby, BC V5A 1S6, Canada \\ ${ }^{9}$ Science and Technology Branch, Environment and Climate Change Canada, Montreal, QC K1A 0H3, Canada \\ ${ }^{10}$ Department of Biological Sciences, University of New Brunswick, Saint John, NB E2L 4L5, Canada \\ ${ }^{11}$ Department of Animal Biosciences, University of Guelph, Guelph, ON N1G 2W1, Canada \\ ${ }^{12}$ Port of Prince Rupert, BC V8J 1A2, Canada \\ ${ }^{13}$ School of Life and Environmental Sciences, Deakin University, Warrnambool, VIC 3280, Australia
}

\begin{abstract}
Increases in global population and seafood demand are occurring simultaneously with fisheries decline in an era of rapid climate change. Aquaculture is well positioned to help meet the world's future seafood needs, but heavy reliance of most global aquaculture on the ambient environment and ecosystem services suggests inherent vulnerability to climate change effects. There are, however, opportunities for adaptation. Engineering and management solutions can reduce exposure to stressors or mitigate stressors through environmental control. Epigenetic adaptation may have the potential to improve stressor tolerance through parental or early life stage exposure. Stressor-resistant traits can be genetically selected for, and maintaining adequate population variability can improve resilience and overall fitness. Information at appropriate time scales is crucial for adaptive response, such as real-time data on stressor levels and/or species' responses, early warning of deleterious events, or prediction of longer-term change. Diet quality and quantity have the potential to meet increasing energetic and nutritional demands associated with mitigating the effects of abiotic and biotic climate change stressors. Research advancements in understanding how climate change affects aquaculture will benefit most from a combination of empirical studies, modelling approaches, and observations at the farm level. Research to support aquaculture adaptation requires an increasing amount of environmental data to guide biological response studies for regional applications. Increased experimental complexity, resources, and duration will be necessary to better understand the effects of multiple stressors. Ultimately, in order for aquaculture sectors to move beyond short-term coping responses, governance initiatives incorporating the changing needs of stakeholders, users, and culture ecosystems as a whole are required to facilitate planned climate change adaptation and mitigation.
\end{abstract}

KEY WORDS: Governance - Monitoring - Data needs - Mitigation · Prediction · Engineering · Research · Stressor 


\section{INTRODUCTION}

Seafood is one of the most highly traded foods internationally (Smith et al. 2010, FAO 2016), and demand is only expected to increase (World Bank 2013). The FAO reports that global capture fisheries have fluctuated between 80 and $90 \mathrm{Mt} \mathrm{yr}^{-1}$ since the mid-1990s, with $50 \%$ capture decrease in the developed world, and reciprocal increase in undeveloped nations since the late 1980s (FAO 2018), with the proportion of globally exploited and overfished stocks increasing since the mid-1970s (FAO 2016). However, other sources have suggested that global catches may have actually peaked at $130 \mathrm{Mt} \mathrm{yr}^{-1}$ in 1996 and have been strongly declining since (Pauly \& Zeller 2016). Nevertheless, while some wild fisheries may experience short-term benefits from climate change, overall global landings are predicted to decrease $10 \%$ by 2050 (Barange et al. 2014). With projected increases in global population and seafood demand occurring simultaneously with ongoing fisheries decline, aquaculture will need to fill this gap.

Global aquaculture production has been steadily increasing for decades, reaching 110.2 Mt in 2016 (including aquatic plants), with the first-sale value estimated at US $\$ 243.5$ billion (FAO 2018). This production has largely been driven by China, accounting for $60 \%$ globally, followed by other major producer nations such as India, Vietnam, Bangladesh, and Egypt. Inland aquaculture systems account for the majority of global production $(47 \mathrm{Mt})$, with most finfish culture occurring in earthen ponds (FAO 2016). Almost 600 different aquatic species are cultured (FAO 2018) in almost 200 countries, with almost a third produced without feed (e.g. bivalves and filter-feeding carps), along with $30.1 \mathrm{Mt} \mathrm{yr}^{-1}$ of seaweeds and other algae (FAO 2016, 2018).

Most global aquaculture culture systems are therefore reliant to a greater or lesser extent on the ambient environment and ecosystem services. This suggests some inherent vulnerability to climate change effects. Nevertheless, due to the capacity to manage captive stock, aquaculture may have an adaptive advantage over wild species under a changing climate (Richards et al. 2015, Oyebola \& Olatunde 2019). Capitalizing on this advantage requires recognizing and learning to respond to climate change effects in order to build adaptive capacity (Cinner et al. 2018). Understanding the effects of climate change on biological responses, resources, and economics in aquaculture is therefore a prerequisite. As climate change effects on aquaculture become better understood, innovative approaches for aquaculture adaptation will help guide strategic planning, which will in turn define needs and expectations for research.

This review explores climate change adaptation strategies with potential application across a range of aquaculture species, regions, and environments. Consequently, the review is organized by strategy and approach, rather than culture system, country, or species. Potential effects of climate change stressors (biotic or abiotic drivers that can be altered by climate change with the potential for negative impacts) are only summarily discussed. This review aims to support pragmatic decision making by operators, managers, policy makers, and researchers, for planned adaptation. Expectations, needs, and practicalities of research implementation required to support meaningful aquaculture adaptation in a multistressor environment are explored.

\section{CLIMATE CHANGE AND AQUACULTURE}

\subsection{Water temperature}

The oceans have absorbed over $90 \%$ of the increase in energy in the climate system, causing the upper 75 $\mathrm{m}$ to warm by $0.11^{\circ} \mathrm{C}$ decade $^{-1}$ between 1971 and 2010 (Rhein et al. 2013). End-of-century model projections for average sea surface temperatures predict increases ranging from (mean $\pm \mathrm{SD}$ ) $0.71 \pm 0.45^{\circ} \mathrm{C}$ (Representative Concentration Pathway [RCP] 4.5) to 2.73 $\pm 0.72^{\circ} \mathrm{C}$ (RCP 8.5) (Howes et al. 2015), with some regional 'hot spots' projected (RCP 8.5) in the Arctic, tropics, and North Pacific, in excess of $4^{\circ} \mathrm{C}$ increase (Bopp et al. 2013, Howes et al. 2015). Marine heat waves will be exacerbated as anthropogenic climate change raises mean temperatures (Schmidt \& Boyd 2016). Global river water temperatures are projected to increase on average by $0.8-1.6^{\circ} \mathrm{C}$ by the end of the century (under the IPCC Special Report on Emission Scenarios B1-A2 scenario) compared to 1971-2000, with the greatest warming projected for the USA, Europe, eastern China, and parts of southern Africa and Australia (van Vliet et al. 2013).

Temperature is an aquaculture driver, and climatedriven temperature change has the potential to influence aquaculture in many ways. Some of these include effects on aerobic fitness (Pörtner 2008), oxygen demand (Fry \& Hart 1948), hypoxia tolerance (Remen et al. 2013), reproductive performance (Pankhurst \& Munday 2011), growth rate (Iwama \& Tautz 1981, Reid et al. 2015), maturation (Wilkinson et al. 2010), nutrition and feeding (Britz et al. 1997, 
Siikavuopio et al. 2012, Khan et al. 2014, Huguet et al. 2015, Remen et al. 2016), energy partitioning (Glencross \& Bermudes 2012), immune response (Bowden et al. 2007, Buchtíková et al. 2011, Chiaramonte et al. 2016), disease proliferation (Burge et al. 2014), seasonal performance (Báez et al. 2011), pond stratification (Pickering et al. 2011), and dissolved oxygen (Timmons et al. 2002).

\subsection{Sea-level rise}

Sea-level rise has the potential to affect coastal aquaculture operations through loss of culture area (Hargreaves 2014), greater and more distant salt intrusion into coastal groundwater (Ahmed 2013, Nguyen et al. 2014, Smajgl et al. 2015, Tully et al. 2019), and, in some areas, the augmentation of seasonal or episodic flooding via storm surges (Wassmann et al. 2004, Rhein et al. 2013). Global mean sea level rose $1.2 \pm 0.2 \mathrm{~mm} \mathrm{yr}^{-1}$ between 1901 and 1990, with this rate increasing to $3.0 \pm 0.7 \mathrm{~mm} \mathrm{yr}^{-1}$ between 1993 and 2010 (Hay et al. 2015). By the end of the $21^{\text {st }}$ century, it is very likely that sea-level rise will have occurred in over $95 \%$ of the world's oceans (Stocker et al. 2013). Small, gradual increases in sea-level rise are not inconsequential, as increased flood inundation is not linear. An increase in sea level by $0.1 \mathrm{~m}$ will increase flood frequency by approximately 3 times (Church et al. 2006, Zhai et al. 2014). Most land-based aquaculture (e.g. pond, hatcheries) is located close to a water source and therefore susceptible to flooding. Flooding can result in escapes, introduction of invasive species (Oyebola \& Olatunde 2019), and contamination of culture water (Adhikari et al. 2018, Kais \& Islam 2018, Oyebola \& Olatunde 2019). Flood-related fish kills may occur for several reasons, but are mainly due to low oxygen in flood waters (Idris et al. 2014). Flood-related mortalities are not uncommon with pond culture (e.g. Bell et al. 2010) and hatcheries (e.g. Lawrence 2016).

\subsection{Changing weather}

Pending El Niño events are expected to drive increased interannual variability in regional temperature extremes (Fasullo et al. 2018), and a near doubling in the frequency of both extreme La Niña and El Niño events is expected within this century (Cai et al. 2014, 2015). El Niño has been linked to massive harmful algal blooms in Chile (in 2015 and 2016), extreme heat, and low dissolved oxygen, damaging
Central American tilapia production (Soto et al. 2018), and slackening trade winds and reducing pond mixing, prompting stratification and hypoxia in Hawaiian fish ponds (McCoy et al. 2017). The effects of climate change on the overall severity and frequency of harmful algal blooms are uncertain (Wells \& Trainer 2016).

Overall, global warming is likely to lead to overall drying of land surfaces due to increased evaporation (Sherwood \& Fu 2014), although regions will vary. Large rainfall changes are projected for a considerable proportion of the tropics by mid-century (Chadwick et al. 2016). Decreases in precipitation will occur in some regions, such as South Asia during summer monsoons (Singh 2016), and increased drought is expected to increase in other areas such as eastern China (Sun et al. 2014), whereas precipitationbased flood frequency will increase in many regions such as Southeast Asia, peninsular India, eastern Africa, the northern half of the Andes (Hirabayashi et al. 2013), the central USA (Rahmani et al. 2016), and parts of Europe (Alfieri et al. 2015). Increased eutrophication due to changes in precipitation and agriculture expansion is expected over the 21st century (Tilman et al. 2001, Sinha et al. 2017). Intensified land run-off may further drive sewage or agricultural fertilizers into coastal production areas where shellfish can become contaminated (Cornelisen et al. 2011) or potentially increase algal blooms, which reduce dissolved oxygen and result in fish mortalities (Díaz et al. 2009).

Storm activity has increased in some ocean basins, such as increased wind stress in the Southern Ocean and increase in average winter wave heights in the North Atlantic (Rhein et al. 2013). There has been greater intensity of tropical cyclones in the North Atlantic since the 1970s (Rhein et al. 2013), and increased occurrences of tropical cyclones in the Caribbean and landfall typhoons in East Asia are expected (Stocker et al. 2013). Changing storminess has recently been identified as having potentially catastrophic impacts for global fisheries, largely due to destruction of vessels, infrastructure, and communities (Sainsbury et al. 2018). Such concerns can be extrapolated to coastal aquaculture, where farms are highly sensitive to storm events (Allison et al. 2009, Rahman \& Hossain 2012, Luening 2013), as evident by the storm-driven destruction of almost entire landbased aquaculture sectors (Reid \& Jackson 2014, Kais \& Islam 2018). Open-water aquaculture is also susceptible to severe weather, with large-scale escapes from sea cages correlated with storm events (Jensen et al. 2010). 


\subsection{Ocean acidification}

Atmospheric increases in anthropogenic carbon dioxide $\left(\mathrm{CO}_{2}\right)$ are raising the concentration of hydrogen ions in the Earth's oceans. The resultant decrease in $\mathrm{pH}$ is known as ocean acidification (Pörtner 2008). Predictions integrating the continued use of fossil fuel have estimated atmospheric $\mathrm{CO}_{2}$ increases from $400 \mathrm{ppm}$ (current levels) to $750 \mathrm{ppm}$ (under the IPCC 1S92a scenario, where atmospheric $\mathrm{CO}_{2}$ concentration rises $1 \% \mathrm{yr}^{-1}$ after 1990) in 2100 , to more than $1500 \mathrm{ppm}$ in the next century (IPCC 2007). The average global ocean $\mathrm{pH}$ has already declined by 0.1 unit (which is an increase in oxygen hydrogen ions of approximately $26 \%$ ) compared with pre-industrial values (Orr et al. 2005) and is predicted to decrease by another 0.4 units by the end of this century (Caldeira \& Wickett 2003). Ocean acidification is occurring more rapidly in coastal and estuarine areas (Waldbusser et al. 2011), which are key aquaculture production zones, with more variable $\mathrm{pH}$ and $\mathrm{CO}_{2}$ levels than those in the open ocean, as local inputs and diel cycles of photosynthesis and respiration can further drive changes in $\mathrm{pH}$ beyond the influence of ocean acidification. Coastal and estuarine $\mathrm{pH}$ can also change due to natural variability, eutrophication, and net heterotrophy (Kemp et al. 2005, Borges \& Gypens 2010), acid-forming compound deposition (Doney et al. 2012), regional changes in land use (Green et al. 2009), and watershed inputs (Dove \& Sammut 2007, Salisbury et al. 2008). The increased partial pressures of carbon dioxide $\left(\mathrm{pCO}_{2}\right)$ diminish the seawater saturation states of aragonite and calcite, the 2 most commonly biomineralized forms of calcium carbonate (Miller et al. 2009) used for the shell formation of some marine organisms.

Experimental outcomes of ocean acidification exposure studies on shellfish can be influenced by numerous variables such as species, acute vs. chronic exposure, animal size, parental exposure, the driver investigated (i.e. $\mathrm{CO}_{2}$, calcium carbonate saturation, $\mathrm{pH})$, magnitude of change, diet availability, and presence of other stressors (e.g. Ries et al. 2009, Thomsen et al. 2010, 2017, Waldbusser et al. 2010, 2015, Gobler et al. 2014, Zhao et al. 2018). To date, negative responses to ocean acidification have been reported in the majority of shelled mollusc larval studies on aquaculture and commercial fisheries species (Gazeau et al. 2013). Most shellfish aquaculture relies either on naturally occurring wild or hatcheryderived juveniles (seed) as the initial stage of production, and therefore decreases in seed abundance will have a significant effect on industry sustainability. Ocean acidification has already had a significant impact on shellfish hatchery production in some regions, such as the US Pacific coast (Ekstrom et al. 2015), whereas later stage (post-larval) shellfish appear to be more resilient to ocean acidification (Green et al. 2009, Waldbusser et al. 2010, Range et al. 2011, Talmage \& Gobler 2011). The impacts of ocean acidification on physiology and reproduction are likely to have significant carry-over effects on the sustainability of future populations of cultured or wild shellfish. In wild finfish, impairments in olfactory responses under elevated $\mathrm{pCO}_{2}$ have been linked to receptor impairment of GABA-A, the primary inhibitory neurotransmitter receptor in the vertebrate brain (Nilsson et al. 2012, Chivers et al. 2014, Chung et al. 2014, Hamilton et al. 2014), but it is unclear how ocean acidification could ultimately affect finfish aquaculture. Marine macroalgal species (seaweeds), which are currently $\mathrm{CO}_{2}$-limited, are expected to benefit from increases in atmospheric $\mathrm{CO}_{2}$ and dissolved $\mathrm{CO}_{2}$ in water (Beardall et al. 1998). In contrast, calcified seaweeds (like crustose coralline algae) will be more susceptible to ocean acidification (Kroeker et al. 2010).

\subsection{Diet}

Approximately $70 \%$ of total global aquaculture production by weight is dependent upon the supply of external feed inputs (Tacon \& Metian 2015), and climate change will affect ingredient sourcing for aquafeeds (De Silva \& Soto 2009, Brugère 2015) and feed management (Shelton 2014). Despite great strides in identification and development of alternative ingredients (e.g. meals derived from soy or corn), small pelagic fish (De Silva \& Soto 2009) are still heavily used for aquafeeds, and reduction fisheries accounted for about $17 \%$ of the global fisheries landings in 2014 (Tacon \& Metian 2015). Some reduction fisheries have been identified as climate-sensitive (Merino et al. 2010, Lindegren et al. 2013, Buchheister et al. 2016). It is therefore expected that climate change may further complicate the relationship between aquaculture and the capture fisheries.

Climate change effects on microalgae (Doney 2006) may also have major implications for some types of aquaculture, since phytoplankton comprise common diets for cultured finfish larvae (through zooplankton), bivalve molluscs, and crustaceans (Wikfors \& Ohno 2001). Warmer and more stratified oceans are expected to shift phytoplankton communities towards 
smaller size with reduced adaptive capacity (AcevedoTrejos et al. 2014) and shift cold-water species ranges poleward (Hallegraeff 2010). Impacts will vary with location (Doney 2006), possibly even benefitting filterfeeding species of shellfish aquaculture in currently nutrient-limited areas (De Silva \& Soto 2009). Climate warming is also expected to decrease the omega-3 fatty acid (FA) content in phytoplankton, the main source of omega-3 FAs in aquatic systems (Hixson \& Arts 2016), and this could have implications for crucial omega-3 FA content in aquafeeds.

\subsection{Simultaneous stressors}

It has been suggested that the greatest threat for sustainable aquaculture development is the cooccurrence and interaction of multiple environmental stressors (Sarà et al. 2018). Simultaneous changes in carbon dioxide, temperature, phytoplankton (community and abundance), salinity, and oxygen are occurring to various degrees through the world's waters (Boyd \& Hutchins 2012, Stramma et al. 2012, P. W. Boyd et al. 2015, Schmidtko et al. 2017). Studies on aquatic species' responses to multiple stressors are still relatively limited and are typically short term and laboratory-based. Research to date has encompassed a variety of aquatic species' responses to simultaneous exposure to changes in ocean acidification and temperature (Byrne et al. 2009, 2013, Matozzo et al. 2012, Brisolin De Souza et al. 2014, Gräns et al. 2014, Graiff et al. 2015, Miller et al. 2015, Suckling et al. 2015), ocean acidification and dissolved oxygen (Gobler et al. 2014, DePasquale et al. 2015, Miller et al. 2016, Sui et al. 2016), salinity and temperature (Choi et al. 2006), and salinity and dissolved oxygen (Wang et al. 2011). Few studies have examined biological responses to more than 2 simultaneous stressors (Catalán et al. 2019). Those that have, reported that multiple stressors that are negatively synergistic may not always be fully additive (i.e. there is interaction), with the greatest biological response often being attributed to a single dominant driver (Brennan \& Collins 2015).

\section{ADAPTATION STRATEGIES}

The wide range of global aquaculture species, regions, and environments that are increasingly exposed to climate change stressors prohibits the examination of specific species-stressor combinations to explore options for adaptation in this discussion.
Nevertheless, commonalities among approaches and strategies can have general applicability across multiple aquaculture sectors. These approaches can be loosely categorized into diet and nutrition; management and engineering solutions; warning of occurring, pending, or future deleterious effects; genetics and biotechnology; and governance. Herein we explore research literature, industry publications, and governance reports that provide insights for aquaculture adaptation to climate change.

\subsection{Diet and nutrition}

\subsubsection{Diet quantity and quality}

There is an energetic cost for organisms acclimating under environmental or biological stressors. Nutrition can therefore influence adaptation potential. For climate change stressors, this has been documented for several mollusc species in response to ocean acidification exposure, where energy intake and assimilation may be unaffected in conditions of plentiful food (Parker et al. 2013, Timmins-Schiffman et al. 2013). Abundant food supply can increase tolerance to high $\mathrm{pCO}_{2}$ and low $\mathrm{pH}$ for blue mussels Mytilus edulis (Melzner et al. 2011, Thomsen et al. 2013) and Pacific oyster Crassostrea (Magallana) gigas larvae (Timmins-Schiffman et al. 2013). A similar compensatory response upon warm water exposure has also been reported. Several shellfish have demonstrated better survival and conditioning from heat shock and thermal stress with abundant diet, such as California mussels M. californianus (Fitzgerald-Dehoog et al. 2012) and juvenile South African abalone Haliotus midae (Vosloo et al. 2013).

Increased demand for dietary energy in response to changing metabolic and physiological demands is consistent with nutritional bioenergetic theory, and existing nutritional strategies may already apply under a changing climate. Nutritional bioenergetic models have been developed for numerous aquaculture species, such as rainbow trout Oncorhynchus mykiss (Hua \& Bureau 2009), Nile tilapia Oreochromis niloticus (Chowdhury et al. 2013), and barramundi Lates calcarifer (Glencross \& Bermudes 2012), to estimate optimal digestible protein and energy requirements under different temperatures.

Diet quality can also affect tolerance to stressors. Providing a high antioxidant diet of grape seed extract and the macroalga Ulva lactuca improved high temperature survival of the greenlip abalone $H$. laevigata (Lange et al. 2014). Experimental evidence 
suggests that purple sea urchins Paracentrotus lividus can improve adaptation to acidification through modulation of the dietary $\mathrm{Mg}: \mathrm{Ca}$ ratio (Asnaghi et al. 2014). Increased dietary protein at elevated temperatures improved blood serum immune parameters, antioxidant enzymes, and heat shock protein gene expression in juvenile mirror (common) carp Cyprinus carpio (Huang et al. 2015). Propolis, a resinous antioxidant honeybee product, improved sea bass resistance to low-temperature stress (Šegvić-Bubić et al. 2013). There may also be a role for dietary immunostimulants to enhance environmental protection (Wang et al. 2017) under a changing climate.

\subsubsection{Feed and diet sourcing}

A decline in reduction fisheries, climate-driven or not, may not necessarily limit global aquaculture expansion. The World Bank, together with the FAO, projected that a steady rise in the price of fishderived feed ingredients will drive technological change and increase conversion efficiency, and consequently, aquaculture growth is expected to continue (World Bank 2013). This is plausible, as the largest consumers of commercial aquaculture feeds have been herbivorous and omnivorous species, namely, the carps, tilapia, shrimp, and catfish species (Tacon \& Metian 2015). The dietary flexibility of these species enables substantially greater opportunities for the use of alternative ingredients compared to carnivorous species (Olsen \& Hasan 2012). Many marine aquaculture species in China, Indonesia, Taiwan, Malaysia, and Thailand are fed almost exclusively with low-value fish, resulting in poor feed conversion efficiency (output:input; fish weight:feed weight) (FAO 2014). Good feed conversion efficiency using low-value fish diets can be achieved with some culture systems (Bunlipatanon et al. 2014), suggesting there could be a more efficient use of this resource. Nevertheless, the FAO (2014) suggested that transitioning to compound feeds would not only increase feed efficiency, but would require only a third of the fish source inputs compared to low-value fish feed. Global aquaculture production will continue to increase, without greatly increased fish meal usage (Olsen \& Hasan 2012), and there have been significant advancements to reduce fish-based ingredients in some aquaculture sectors with cultured carnivorous species. For example, $1 \mathrm{~kg}$ of protein in the edible portion of Atlantic salmon can now be produced from $0.7 \mathrm{~kg}$ of marine protein, resulting in a net production of marine protein (Ytrestøyl et al. 2015).

Several nutritional sourcing strategies have been advocated to meet current challenges while promoting climate change adaptation. These include sourcing nutritionally sound feed ingredients at the local level (Tacon et al. 2011); pursuing 'underutilized' alternative crops, resistant to drought and temperature, with good nutritional properties (Hall 2015); promoting rice-fish farming systems (J. Xie et al. 2011, B. Xie et al. 2013, Shelton 2014); and implementing integrated multi-trophic aquaculture (IMTA) to augment diet through increased use of waste organic and dissolved (inorganic) nutrients (Chopin et al. 2012, Reid et al. 2013). While sourcing aquaculture feed ingredients from terrestrial crops may relieve some resource pressure from the marine environment, there is a concern that environmental impacts could shift to those associated with increased crop demand (Fry et al. 2016), especially when global crop output for 2050 is projected to be insufficient for global demand (Ray et al. 2013, Asseng et al. 2015). It has been further suggested that terrestrial crops for aquafeeds may have negative implications for human health such as the reduced omega-3 FA content associated with terrestrial ingredients (Fry et al. 2016). Nevertheless, marine sources of omega-3 FAs may become less reliable. New supplies of omega-3 FAs will need to be found, and this is an area of ongoing investigation as reviewed by Tocher (2015).

Enabling good nutritional access for species that extract their diet from the environment under a changing climate is likely to present a suite of challenges as well as opportunities. Dietary control will be a much greater challenge for species that extract their nutrition from the ambient environment such as shellfish and seaweeds, where changing climatic conditions will directly influence the quality and quantity of available nutrition. Farm relocation is one potential solution (Soto et al. 2018). Rearing systems such as land-based aquaculture could also enable more dietary control with extractive species, but this may come at an increased cost to other resources such as infrastructure requirements, land usage, and water pumping.

\subsection{Genetics and biotechnology}

The epigenetic response potential of fishes (Pittman et al. 2013) and marine invertebrates (Sanford \& Kelly 2011) suggests some level of adaptive capacity to climate change, but there are significant 
knowledge gaps. For example, the capacity for marine populations to adapt to increased acidity is largely unknown, as few studies have considered acclimation times of more than a few months (Harley et al. 2006, Kurihara et al. 2007, Doney et al. 2009, Thomsen et al. 2010, Gazeau et al. 2013) or with relevant exposure levels. Aquaculture-based populations are less likely to be impacted due to the potential to manipulate culture conditions (Richards et al. 2015). Plastic responses, particularly in early life stages, suggest that greater environmental control during early rearing may help direct adaptive epigenetic responses. Hatcheries are already well positioned to use this strategy.

Selective breeding programmes for desirable traits are already common in aquaculture, and this may provide additional options for climate change adaptation. Generational improvements have the potential to occur rapidly for some traits. Some of the most globally produced culture species, such as carps (Puntius gonionotus, Labeo rohita, Cyprinus carpio) and prawns (Macrobrachium rosenbergii), have reported productivity gains ranging from 7 to $12 \%$ per generation, through application of conventional selective breeding approaches (Nguyen 2016). There is also compelling anecdotal evidence that environmental stressor tolerance traits may 'evolve' under culture conditions. Ellis et al. (2017) reported that finfish in recirculated aquaculture systems are routinely raised in high- $\mathrm{CO}_{2}$ environments, often in excess of end-of-century predictions, sometimes $>10000 \mu \mathrm{atm}$, with no apparent ill effects. While this apparent discrepancy from many studies on wild species could be for several reasons, the authors suggested one possibility may be that aquaculture species selection and breeding under intensive culture environments may have conferred greater tolerance to high $\mathrm{CO}_{2}$. Oyster breeding programmes that have experienced declines in survival and yield related to changing ocean conditions (de Melo et al. 2016) are now selecting for increased calcification rates (Waldbusser et al. 2010). Organisms adapted to local carbonate chemistry indicate that spatially varying selection could provide adaptive traits and maintain genetic variation (Kelly et al. 2013), and given variable sensitivities to ocean acidification between strains of Sydney rock oysters Saccostrea glomerata, selective breeding is being advocated (Parker et al. 2011). Salinity-tolerant strains of shark catfish Pangasianodon hypophthalmus are now being developed to adapt to saline water intrusion from floods in the Mekong Delta, Vietnam (Nguyen et al. 2014). Adaptation through domestication of a variety of species tolerant to climatic varia- tions may also reduce dependency on wild-caught seed (Oyebola \& Olatunde 2019).

Specific climate change performance traits may warrant consideration in broodstock selection programmes. Genomic approaches may be necessary to fully exploit these traits or improve traits at a rate sufficient to match the rate of climate change. When there is no possibility to include climate changerelated traits into a broodstock programme, retaining as much genetic variability as possible in the breeding nucleus should be a priority. The success of the genetic improvement programmes for carp, tilapia, and prawns are in part due to the establishment of respective base populations with ample genetic variability (Nguyen 2016). Maintenance of genetic diversity could ensure preservation of rare alleles that might be associated with resistance to a future disease or increased survival to environmental stressors (Gurney-Smith et al. 2017). While there is immense potential for breeding programmes to improve resistance to climate change stressors, experience suggests that domestication does not always result in improved fitness compared to wild counterparts (Araki et al. 2008), and there are numerous challenges to overcome, including environment effects, like climate change, on genotype stability (Nguyen 2016). Breeding programmes also require a mediumto long-term investment (Nguyen et al. 2016) and may not be easily attainable for subsistence farmers.

There are also encouraging biotechnological options. If the rate of climate change supersedes breeding schemes based on recorded phenotypic data, including molecular selection techniques (e.g. genomic marker-assisted selection) with phenotypic selection programmes may be necessary. Advancements in commercial-scale cryopreservation enable 'gene banking' or retention of genetics from one parent (male) regardless of continued inclusion in a brood stock programme, and viable larval preservation protocols have been and are being developed for some marine shellfish (e.g. Adams et al. 2004), depending on species. Consequently, gene or germplasm banking approaches have been advocated as a biological insurance for future needs of aquaculture breeding and stock selection (Hulata 2001, Barrento et al. 2016).

\subsection{Management and engineering solutions}

The global aquaculture sector has demonstrated great ingenuity and adaptability, as reflected by the immense diversity of species cultured in vastly 
different environments. This capacity for creative problem-solving will ultimately be required for climate change adaptation. At their simplest, adaptation strategies are likely to be based around management and husbandry practices (McCoy et al. 2017, Adhikari et al. 2018). These practices are often accompanied by engineering solutions, so both will be considered together.

\subsubsection{Flooding and storm protection}

Protection against floods will be a combination of management strategies and age-old engineering approaches, such as increasing physical barriers or use of tanks and inland enclosures (Kais \& Islam 2018, Oyebola \& Olatunde 2019). The scope of response will be a function of damage potential. An increase in sea level of $0.1 \mathrm{~m}$ requires coastal infrastructure such as wharfs to be raised by $>0.1 \mathrm{~m}$ (an allowance) in order for the same historical flood frequency to be maintained (Zhai et al. 2014). Some flood-response management strategies are already routine in regions with predictable seasonal flooding. For example, in Malaysia, fish are harvested prior to known flood periods in areas prone to episodic flooding (Idris et al. 2014). Likewise in Taiwan, pond water levels are dropped prior to flooding (Chang et al. 2013), and excess water volume is pumped out of ponds in some Indian regions (Adhikari et al. 2018). Nets are placed around shrimp farms to prevent escapes during heavy rains and flooding in some regions of Bangladesh (Kais \& Islam 2018) and fish ponds in India (Adhikari et al. 2018). Fish evacuation or movement to safer culture areas may be necessary where flooding can overtop tanks or ponds (Dodd 2011, Adhikari et al. 2018).

Protection of land-based coastal aquaculture against storm surges can be improved with natural barriers, such as mangroves (Ahmed \& Glaser 2016, Chow 2018) reefs, and coastal vegetation (Arkema et al. 2013). Giving up some coastal culture ponds in Java has been advocated to protect some residual mangroves (Bosma et al. 2017), and the translocation of shrimp culture from mangrove swamps to offshore aquaculture has been suggested as a way to reduce mangrove loss while increasing carbon sequestration (Ahmed et al. 2017). Some initiatives are increasing the percent coverage of mangroves in integrated mangrove-shrimp farming areas (Ahmed et al. 2018) and restoring coastal mangroves in abandoned shrimp ponds (Friess et al. 2016). Seaweed aquaculture has also been suggested as a strategy to dampen incoming wave energy and protect shorelines (Duarte et al. 2017).

In some instances, flooding could expand aquaculture opportunities. Some aquaculture fisheries rely on flooding to fill water bodies with wild fish for culture, such as floodplain ponds in Kenya (Kipkemboi et al. 2010) or Whedo aquaculture systems in west Africa (Hauber et al. 2011). Flooded land which is no longer suitable for agriculture could provide new opportunities for aquaculture (IFAD 2014). Areas rendered unsuitable for traditional agriculture (e.g. rice farming) as a result of saltwater intrusion could be repurposed for shrimp farming (De Silva \& Soto 2009).

Weather extremes associated with climate change may increase escapes and negatively affect pathogens and hosts, emphasizing the need for good biosecurity under a changing climate (Bondad-Reantaso et al. 2018). Uncertainties in storm extremes have introduced additional considerations for the design of aquaculture facilities (Alvarez-Lajonchère \& PérezRoa 2012). Storm intensity duration frequency (IDF) curves are used by engineers to guide design specifications; these are changing and being updated for new climate scenarios and predictions (Liew et al. 2014). Aquaculture infrastructure design will likewise need to account for changes in storm IDF, or redesign efforts may become necessary due to structural failure (Can \& Tuan 2012). Fish cages need to withstand powerful waves under a changing climate (Binh et al. 2017). Developments in off-shore aquaculture, such as submersible systems for both finfish (Shainee et al. 2014) and shellfish (Kim et al. 2014), have already spurred technologies capable of withstanding high energy exposure for open-water aquaculture (Shainee et al. 2013).

\subsubsection{Relocation}

Choosing farm locations less impacted by climate change effects is an intuitive adaptation strategy, and the inclusion of climate change and other risks into spatial planning and aquaculture zoning has been advocated as an approach to reduce impact exposure (FAO 2016). Some shellfish hatcheries have already relocated to less acidic waters (Welch 2012). GIS or remote sensing tools have been used for some time to select appropriate aquaculture locations (Nath et al. 2000, Perez et al. 2005, Hossain et al. 2007, Radiarta et al. 2008, Hossain \& Das 2010, Mamat et al. 2014, Brigolin et al. 2015, Dapueto et al. 2015, Ottinger et al. 2016), and these are now being used to identify 
culture areas less prone to sea-level rise, drought, thermal stress, and flooding (Handisyde et al. 2008, 2014, Hossain \& Das 2010, Khan et al. 2012, Aura et al. 2017). Deeper ponds can provide a thermal refuge and greater dissolved oxygen reserves and are less sensitive to environmental factors in dry seasons (Soto et al. 2018).

A locational adaption strategy could also reduce disease, limiting pathogen or parasite exchange between wild and cultivated species (Peeler \& Feist 2011, Lafferty et al. 2015). A potential complicating factor with relocating to areas of optimal water quality is that conditions may not be optimal for all life stages. Báez et al. (2011) reported that for rainbow trout, the fastest growth rates occurred at temperatures which are detrimental to reproductive performance, and have advocated separate site locations for broodstock and grow-out to ensure optional temperatures across the full life cycle. This has implications for the required resources, infrastructure, and expertise to facilitate these adaptive goals.

\subsubsection{Localized mitigation}

In some circumstances, direct mitigation of the localized environment is possible, and this is achievable with the most common method of global aquaculture production, pond culture. While ponds are exposed to the open environment, a high degree of control over environmental variables through water management, aeration, protective cover, and water treatment is possible (Lorenzen et al. 2017). Oxygen tablets and aeration can augment dissolved oxygen, pumping in freshwater can supplement water during the dry season, and along with shading and increased depth $(>1 \mathrm{~m})$, this can reduce pond temperatures (Binh et al. 2017, Adhikari et al. 2018). For infaunal marine species in detrimental sediment saturation states, sediment buffering using crushed shell has been tested to increase sediment alkalinity, $\mathrm{pH}$, and aragonite saturation states, thereby decreasing shell dissolution and/or promoting larval recruitment (Green et al. 2009). Seaweed or macrophyte culture has been suggested as a method to provide localized mitigation, act as a net producer of oxygen, sequester carbon dioxide, and increase $\mathrm{pH}$ (De Silva \& Soto 2009, Han et al. 2013, Clements \& Chopin 2017, Duarte et al. 2017, Wahl et al. 2018), although effectiveness will depend upon many factors such as species, culture system, production scale, nutrient load, water flow, latitude, irradiance, and production timing (Broch et al. 2013, Reid et al. 2013, Hurd 2015). Land-based or closed containment rearing strategies could be options to either protect sensitive life stages from environmental stressors or control rearing conditions to enable adaptive responses (see Section 3.2). These strategies enable water quality control through either recirculation approaches (Timmons et al. 2002), strategic water intake to avoid periodic stressors such as $\mathrm{CO}_{2}$ upwelling (Barton et al. 2012), or through bio-buffering.

\subsubsection{Diversification}

Culture diversification is a common historical approach as a contingency to spread the risk against losses. Globally, aquaculture species produced are highly diverse, covering many regions, environmental conditions, and trophic levels. Such diversity has the potential to enable selection of alternative species should one species become non-viable under regional climate change. Aquaculture practices, such as polyculture and IMTA, at the farm level are options that can enable continued production if one crop fails (Chopin et al. 2012, Oyebola \& Olatunde 2019) and are advocated for climate change adaptation (Binh et al. 2017). Co-culture not only serves the dual purpose of expanding diversity and enhancing the use of nutrients, but can also reduce competition for other resources such as water, through integrated aquaculture and agriculture systems, in addition to improving water quality (IFAD 2014, Shelton 2014, Oyebola \& Olatunde 2019). In developing countries where there is intense competition for space and resources, there may also be considerable future expansion of culture-based fisheries, an extensive aquaculture practice based on the principle of stock and recapture (De Silva 2016, Oyebola \& Olatunde 2019). This approach has the potential to address climate change-related issues of wild stock recruitment requiring minimal feed use and care (Beveridge et al. 2018). There is increasing interest in culturing species which have the capacity to breathe air, and this could be a viable option where water quality is poor (Lefevre et al. 2014).

\subsection{Improving information}

Timely information can enable management responses and strategic planning, from real-time, to forecasting early warning, to prediction over long time scales. Initiatives to promote local-level adapta- 
tion through training, data collection, analysis, and sharing, are advocated as an approach to connect environmental data with broader forecasts to support decision making by local aquaculture stakeholders (FAO 2016, Oyebola \& Olatunde 2019).

\subsubsection{Real-time monitoring}

Real-time monitoring can alert farmers to the presence of deleterious conditions that may not be obvious until the onset of behavioural or clinical symptoms in the stock. Monitoring is routine for parameters such as oxygen and temperature in many aquaculture sectors, but recent developments in technology and networking have greatly expanded breadth and capability. Near real-time water quality is available though some ocean condition monitoring networks (e.g. Integrated Ocean Observing System [IOOS, https://ioos.noaa.gov/] and regional nodes such as the Northwest Association of Networked Ocean Observing Systems [NANOOS; http://nvs. nanoos.org/ShellfishGrowers]) which allow aquaculturists to track crucial water quality parameters online for informed management decision-making (e.g. IOOS). Some monitoring stations are located directly at aquaculture sites with industry participation (e.g. NANOOS). In the absence of detailed water quality data, animal behavioural cues are often indicators of environmental stress. Observation is difficult with some species, like many shellfish, that exhibit limited behavioural cues upon the onset of environmental stress. This has spurred recent developments in microsensor technology which now enable shellfish heart rates to be monitored in sentinel animals, as a means to assess real-time response to environmental or biological stressors (Hellicar et al. 2015). New metrics are now being considered such as shell thickness and condition index of mussels to assess thermal impacts on the shellfish aquaculture sector (Martinez et al. 2018).

\subsubsection{Early warning}

Early warning of acute, deleterious events can improve response times of farmers (Nguyen et al. 2015). Aquaculturists can be alerted to pending weather conditions in some Chinese regions, and seasonal predictions of water temperature are now available in Australia (Spillman \& Hobday 2014). Avoiding the use of low aragonite-saturated waters under strong upwelling conditions has enabled sig- nificant restoration of oyster hatchery production in the US Pacific Northwest (Barton et al. 2012). Adequate warning of stressful environmental events may also enable intervention time to bolster the immune system at times when species are known to be immunosuppressed, through changes such as photoperiod manipulation or the application of immunomodulators (Bowden et al. 2007). Early warning systems have been strongly advocated in order to reduce aquatic food safety risk posed by climate change-related natural disasters, such as contamination (e.g. pathogens) from extreme weather events (Cornelisen et al. 2011, Bondad-Reantaso et al. 2018).

\subsubsection{Prediction}

Aquaculture sectors can clearly benefit from longterm climate predictions of environmental variables. For example, templates of Tasmanian sea surface temperature projections can be applied by managers to identify onset years when some regions will become unsuitable for the culture of certain species (Hobday et al. 2018). However, one of the most pressing predictive needs is arguably predicting disease outbreak. Limitations in monitoring and prediction of disease outbreaks could be major hurdles for climate change adaption for some aquaculture sectors. Early detection followed by quick targeted responses can reduce the impact of disease (Peeler \& Feist 2011, Groner et al. 2016). Tracking serious and potentially reoccurring infections is a common practice for some developed regions, but baseline data are also required for determining prevalence and distribution of pathogens and parasites in wild species before establishing operations to prevent transfer (Lafferty et al. 2015). There are some encouraging developments such as web-based management programmes that maintain an epidemiological database, tracking temporal and spatial trends of farm infections, and environmental conditions for decision support (e.g. Harris 2015). However, at the global scale, most disease outbreaks are unreported. There is a lack of standardized reporting of aquaculture-based epizootics and conditions surrounding outbreaks, which is needed to help formulate adaptation strategies under climate extremes (Leung \& Bates 2013). Enhanced reporting on disease prevalence is necessary for better understanding of climate influences. While effective disease surveillance needs to start with farmers (Brugere et al. 2017), epidemiological modelling has the potential to predict the spread of some aquaculture diseases under a changing climate 
(Lafferty 2009). The use of GIS-based statistical models that enable spatially distributed determinants of aquatic health and disease for risk mapping have been encouraged (Thrush et al. 2011). However, these models are data-driven, which further emphasizes the need for detailed reporting, interdisciplinary approaches to mitigate disease impacts in aquatic systems (Adlard et al. 2015), and additional research on effects of environmental change on disease (Lafferty et al. 2015).

\subsection{Governance}

Climate change has been described as a complex and diabolical policy problem that poses difficult challenges for contemporary political systems (Steffen et al. 2011). It is an inherently global problem that has been the subject of international negotiations for over 20 yr. While parties to the United Nations Framework Convention on Climate Change (UNFCCC) meeting at COP21 (also known as the 2015 Paris Climate Conference) have reached an accord on emission limits, global annual emissions are expected to rise to 2030. The anticipated increase in emissions is likely to be inconsistent with the international goal of limiting the rise in global mean surface temperature to no more than $2^{\circ} \mathrm{C}$ above preindustrial levels (Rogelj et al. 2013, R. Boyd et al. 2015). This has raised concerns that the current climate policy promises, based on voluntary intended nationally determined contributions, will do little to stabilize the climate, and that their impact will be undetectable for many decades (Lomborg 2016).

In response to the challenges and opportunities posed by climate change, many countries have developed national comprehensive climate change adaptation strategies (e.g. Fransen et al. 2009, DEE 2015, SEMARNAT-INECC 2016). These plans acknowledge the wide-ranging impacts of climate change, and set out plans and targets for reducing greenhouse gas emissions. However, they seldom include specific adaptation and/or mitigation strategies for aquaculture. In the near term, climate change will have many direct impacts on aquatic farming systems, which will bring new challenges to maintaining sustainability. As noted by the FAO (2015) and others (Paprocki \& Huq 2018), aquaculture will need to be integrated into national and regional adaptation plans, as otherwise it could suffer as a result of adaptation measures applied to other sectors.

The type and intensity of the impacts climate change will have on aquaculture will vary between continents, countries, climatic regimes, and production systems. In practical terms, there is a need for local, regional, and national governments to establish regulatory policy and frameworks that will help direct aquaculture onto the most climate changeadaptive and resilient paths possible (Craig 2015). Decision-makers should examine their adaptation strategies/policies/activities over a wide range of plausible futures (e.g. RCP scenarios) to choose a strategy that is sufficiently robust to not only account for uncertainties of climate prediction but other economic, political, and cultural factors as well (Dessai et al. 2009). Although adaptation strategies will be influenced by sector and regional specifics, a number of actions can be applied to most aquaculture. In an FAO series of international case studies on regional climate change adaptive capacity of fisheries and aquaculture, Brugère (2015) concluded that ecosystem resilience and human adaptive capacity were the 2 major determinants of vulnerability, and that governance was itself a determinant of adaptive capacity. Fisheries and aquaculture will require a variety of policy and governance initiatives to facilitate planned climate change adaptation, which typically necessitates more effort and cost, and are focussed on much longer time scales, compared to shorter-term coping responses (Shelton 2014). Owing to the cross-cutting nature of climate change effects, policies that are designed to conserve biodiversity, reduce external stressors on aquatic systems, and/or protect valuable natural areas as well as endangered species will all benefit aquaculture.

A consistent theme echoed by academics, NGOs, and national and international government agencies is that in the face of rising global demand for food, aquatic farming systems must not only adapt to ongoing and pending environmental changes in order to sustain production levels, but also increase production significantly. There is great potential for aquaculture to adapt, innovate, and expand. However, regulatory frameworks are complex, expensive for farmers to navigate, and slow to respond to technological innovations (Alexander et al. 2015, Bostock et al. 2016). In both developed and developing nations, there are calls for regulatory reforms to reduce red tape, improve certainties for operators so that they can obtain access to space and water (e.g. Watson 2015, James 2016), and provide trained specialists to analyse and implement adaptation strategies (Binh et al. 2017). While there is a need to maintain and, in some instances, improve environmental regulation within the industry, streamlining of regulatory regimes would go far to help the sector adapt and diversify. 


\section{RESEARCH CONSIDERATIONS TO SUPPORT AQUACULTURE ADAPTATION}

Many farmers are currently dealing with climate change problems through short-term coping measures which ultimately need scientific improvements to support long-term solutions (Dubey et al. 2017). Investments in research and technology transfer are needed to develop sustainability and support climate change adaptation in aquaculture (Uppanunchai et al. 2018). The FAO has recognized the need to build capacity of institutions to integrate research, management, and policy while enabling partnerships between science and policy institutions, so that research is developed at relevant scales for decisionmaking (FAO 2018). While there is acknowledgement of strategic research needs required to develop adaptation, there are also tactical research challenges for both single and multiple stressors that require exploration to support informed research planning.

\subsection{Environmental data needs}

Climate information complements and rounds out adaptation and mitigation strategies (Trenberth et al. 2016). While some progress has been made in understanding aquaculture vulnerability to climate change, more research is needed to quantify the driving processes and develop alternative aquaculture approaches and practices accordingly (FAO 2016). Consequently, environmental data limitations and accessibility can be major impediments for conducting biological response research.

A formidable research challenge is accurately and precisely determining how environmental changes will affect the physical culture environment and therefore what conditions need to be simulated to run valid experiments. One example are the knowledge gaps regarding changes in coastal marine culture environments. Biological studies often employ conditions of future scenarios (e.g. from the IPCC) based upon stable atmospheric conditions (Riebesell et al. 2010) rather than more variable coastal in situ environments where most marine aquaculture occurs. Ocean carbonate system parameters are highly variable in response to changes in temperature and salinity (Riebesell et al. 2010), and quantifying ocean acidification at regional scales requires knowledge of the natural variability of ocean carbonate ion concentrations at seasonal, annual, and even greater timescales (Friedrich et al. 2012). Currently, there is little spatial and temporal resolution of $\mathrm{pH}$, $\mathrm{pCO}_{2}$, salinity, alkalinity, oxygen, and temperature data at biologically relevant scales and locations, which also restricts our ability to identify areas where contemporary climate change may have already occurred. A better understanding of true coastal environmental conditions and how these will change under climate change scenarios would allow more realistic biological stressor studies (Reum et al. 2016), while enabling greater predictive capacity of adaptation potential (Riebesell \& Gattuso 2015).

Data deficiency or limited data accessibility is particularity acute for certain culture regions. Over half of the world's inland fish culture occurs in China (FAO 2014), primarily in ponds and river delta areas of southeast China (Wang et al. 2015). Lack of accessible relevant environmental data and only a few published regional climate predictions (e.g. Zhang et al. 2006) makes planning for climate change for the largest portion of global aquaculture production particularly daunting. In other regions, such as North America, high-resolution water quality data (e.g. temperature, oxygen) have been collected at culture sites for decades by industry, but there has been no concerted effort to compile and analyse these data to disentangle climate change effects which could assist in aquaculture adaptation (Reid \& Gurney-Smith 2016).

Environmental data sharing is one option to maximize resources, but this requires continuity and significant coordinated effort. While day-to-day operational water quality data are often collected by farmers, longer-term data sets are needed to help quantify timelines of regional effects. Although longterm temporal data collection programmes have been quantitatively demonstrated to improve ecosystem models and forecasts (Giron-Nava et al. 2017), such datasets are rare. In the ocean environment, this type of data collection has often been the purview of marine stations, but many stations throughout the world are consistently in danger of closing, observations are not financially supported, and long-term data collection requires significant investment (Boero et al. 2015). In an era of fiscal restraint, resources and support from multiple-user communities, environmental stewards and data collection initiatives, including citizen science and regional partnerships (Chambers et al. 2017), are needed to ensure essential data collection and effective research. Such commitments are not trivial. Successful data-sharing initiatives have typically been backed by significant government support, resources, and coastal user communities (e.g. IOOS). 


\subsection{Expectations of increased research complexity}

A proactive, multidisciplinary approach is required to reconcile multiple stressors in setting sustainable aquaculture development standards and designing adaptive management solutions (Sarà et al. 2018). Interdisciplinary research is not only crucial for the growth and development of aquaculture (Engle 2016), but also for understanding how multiple climate change stressors affect biological responses. Considerable complexity can therefore be expected in both aquaculture and climate change research, as they are inherently multidisciplinary. Disentangling the interplay of multiple stressors over relevant production timeframes introduces even further complexity, because it is generally not possible to extrapolate biological responses from single to multiple stressors (Riebesell \& Gattuso 2015). Stressor combinations that are negatively synergistic may not always be fully additive; they may buffer (Humphreys 2017) or interact, and the greatest biological response may be attributed to a single dominant driver (Brennan \& Collins 2015). Not only can stressor interaction confound biological responses, but a poor understanding of interactive stressor effects on water chemistry (Kroeker et al. 2014) can lead to misinterpretation of environmental impacts. The duration of experimental trials is another important consideration, as it has the potential to confound results. Selecting plants, algae, or animals from the wild or farms for short-term laboratory exposure to single stressor magnitudes does not allow good opportunity to assess adaptive responses, account for interaction between stressors, or reflect rates of change. Exploring longer-term biological responses and reconciling water chemistry changes under combined stressors will produce more meaningful research results.

The increased complexity of long-term multi-stressor research will result in an increased need for research resources and logistics. Increasing the number of stressors examined in environmentally relevant climate combinations results in a non-linear increase in the number of research culture units required. Even a simple multi-factorial study applying 3 stressors at 3 different magnitudes with 3 replicates per treatment requires 81 experimental units to be scientifically robust. As experimental needs for identical experimental culture units increase, the number of research facilities or culture sites that can accommodate large numbers of identical culture units becomes fewer. If the research involves 'large' animals, proportionate culture size units (e.g. tanks) will require even greater space along with other resource pressures associated with the infrastructure (e.g. water, electricity, maintenance). Experiments across a full production cycle could be on the order of years and require prolonged occupation of culture units, reducing availability for other research, which would be further compounded in considerations of transgenerational research.

A comparison of environmental variation of historical data sets with present-day variation is needed to assess and help predict changes in frequency, scale of extremes, and phenology important to aquaculture stakeholders. Changes in environmental variation at different scales may affect aquaculture species through increased energy costs (Mangan et al. 2017), changes to infection dynamics (Rohr et al. 2011, Altizer et al. 2013, Groner et al. 2014), and physiological responses (Hori et al. 2013). It has been advocated that forthcoming IPCC reports include variability forecasts of surface temperatures and $\mathrm{pH}$ of both natural and anthropogenic drivers to better infer how key organisms and ecosystems respond to climate change (Schmidt \& Boyd 2016).

This logical progression towards data sharing and the exponentially increasing number of climate change studies (Haunschild et al. 2016, Pedersen et al. 2016, Xu et al. 2016) suggest a need for the standardization of some research methodologies. Such standardization may require accepted data collection methodologies, best practices for experimental designs, standardized apparatus and perturbations, biological reference organisms for in situ studies, standardized reporting, consideration of natural fluctuations, and more realistic simulation of regional environmental conditions to facilitate research progress and data interpretation (Riebesell et al. 2010, Boyd 2013, Riebesell \& Gattuso 2015, Boyd et al. 2016, Cornwall \& Hurd 2016, Ellis et al. 2017). Progress in this respect has occurred in some fields such as ocean acidification research (Riebesell et al. 2010). However, standardization is not without its complications either. Concerns have been expressed that experiments run at standardized levels may not account for local adaption, and adaptive plasticity may confound interpretation of inter-population differential responses (Vargas et al. 2017). Nevertheless, these considerations require wider discussion. An increase in data requirements, research complexity, and scope of biological response research are to be expected, which will ultimately benefit from collaborative approaches to facilitate and optimize research outcomes. 


\section{CONCLUSIONS}

Reconciling current and pending effects of climate change on aquaculture may be daunting, but the potential for a range of adaptation options provides some encouragement. There are many options for aquaculture adaptation to climate change, from simple management changes to complex engineering or biotechnology solutions. These can be applied at the farm management level or be driven by wider governance initiatives. A range of adaptation success is to be expected. Some adaption will be planned and initiated to precede impacts, while other adaptations will be reactive. Some aquaculture sectors may be unable to adapt, while there will be opportunities for new sectors.

The wide range of climate change adaptation options suggests the need for research engagement at all levels. Adaptation to climate change is apt to be most effective when supported by research; whether through traditional subsidised science (government, academia, environmental NGOs), industrydriven research and development, or trial and error solutions by farmers. Effective advancements in aquaculture adaptation will benefit from research teams comprising diverse expertise and a combination of empirical studies, modelling approaches, and observations at the farm level. When only complex adaptation solutions are viable, increased research complexity and expertise will translate into increased costs. As research becomes more expensive, it will become less accessible to small-scale farmers that comprise the bulk of global aquaculture production, and therefore research avenues are likely to require ongoing support by subsidised science.

Changes to our climate are being documented around the globe, daily. Collectively, these changes have profound implications for the aquaculture sector and its ability to contribute to long-term global nutrition and food security. Governments and aquaculture producers have little choice but to develop measures to adapt to changes in environmental conditions that are being thrust upon them. Adaptation is not mitigation, however, and ultimately, the longterm solution to climate change is the reduction of green-house gases along with other deleterious anthropogenic impacts.

Acknowledgements. Thank you to the Canadian Integrated Multi-Trophic Aquaculture Network, a strategic network of the Natural Sciences and Engineering Research Council of Canada.

\section{LITERATURE CITED}

Acevedo-Trejos E, Brandt G, Steinacher M, Merico A (2014) A glimpse into the future composition of marine phytoplankton communities. Front Mar Sci 1:15

Adams SL, Smith JF, Roberts RD, Janke AR and others (2004) Cryopreservation of sperm of the Pacific oyster (Crassostrea gigas): development of a practical method for commercial spat production. Aquaculture 242:271-282

Adhikari S, Chaudhury AK, Gangadhar B, Ramesh R and others (2018) Adaptation and mitigation strategies of climate change impact in freshwater aquaculture in some states of India. J FisheriesSciences.com 12:016-021

Adlard RD, Miller TL, Smit NJ (2015) The butterfly effect: parasite diversity, environment, and emerging disease in aquatic wildlife. Trends Parasitol 31:160-166

Ahmed N (2013) Climate change impacts on human health in freshwater prawn farming communities in Bangladesh. Aquacult Mag 44:28-43

Ahmed N, Glaser M (2016) Coastal aquaculture, mangrove deforestation and blue carbon emissions: Is REDD+ a solution? Mar Policy 66:58-66

Ahmed N, Bunting SW, Glaser M, Flaherty MS, Diana JS (2017) Can greening of aquaculture sequester blue carbon? Ambio 46:468-477

Ahmed N, Thompson S, Glaser M (2018) Integrated mangrove-shrimp cultivation: potential for blue carbon sequestration. Ambio 47:441-452

Alexander KA, Potts TP, Freeman S, Israel D and others (2015) The implications of aquaculture policy and regulation for the development of integrated multi-trophic aquaculture in Europe. Aquaculture 443:16-23

Alfieri L, Feyen L, Dottori F, Bianchi A (2015) Ensemble flood risk assessment in Europe under high end climate scenarios. Glob Environ Change 35:199-212

Allison EH, Perry AL, Badjeck MC, Adger WN and others (2009) Vulnerability of national economies to the impacts of climate change on fisheries. Fish Fish 10:173-196

Altizer S, Ostfeld RS, Johnson PTJ, Kutz S, Harvell CD (2013) Climate change and infectious diseases: from evidence to a predictive framework. Science 341:514-519

Alvarez-Lajonchère L, Pérez-Roa R (2012) Site selection for tropical marine fish hatchery and its application in the Caribbean coast of Nicaragua. Aquacult Eng 46:10-17

Araki H, Berejikian BA, Ford MJ, Blouin MS (2008) Fitness of hatchery-reared salmonids in the wild. Evol Appl 1: 342-355

Arkema KK, Guannel G, Verutes G, Wood SA and others (2013) Coastal habitats shield people and property from sea-level rise and storms. Nat Clim Change 3:913-918

Asnaghi V, Mangialajo L, Gattuso JP, Francour P, Privitera D, Chiantore M (2014) Effects of ocean acidification and diet on thickness and carbonate elemental composition of the test of juvenile sea urchins. Mar Environ Res 93:78-84

* Asseng S, Ewert F, Martre P, Rötter RP and others (2015) Rising temperatures reduce global wheat production. Nat Clim Change 5:143-147

Aura CM, Musa S, Osore MK, Kimani E and others (2017) Quantification of climate change implications for waterbased management: a case study of oyster suitability sites occurrence model along the Kenya coast. J Mar Syst 165:27-35

Báez VH, Aigo JD, Cussac VE (2011) Climate change and fish culture in Patagonia: present situation and perspectives. Aquacult Res 42:787-796 
Barange M, Merino G, Blanchard JL, Scholtens J and others (2014) Impacts of climate change on marine ecosystem production in societies dependent on fisheries. Nat Clim Change 4:211-216

Barrento S, Camus C, Sousa-Pinto I, Buschmann AH (2016) Germplasm banking of the giant kelp: our biological insurance in a changing environment. Algal Res 13: 134-140

* Barton A, Hales B, Waldbusser G, Langdon C, Feely RA (2012) The Pacific oyster, Crassostrea gigas, shows negative correlation to naturally elevated carbon dioxide levels: implications for near-term ocean acidification effects. Limnol Oceanogr 57:698-710

Beardall J, Beer S, Raven JA (1998) Biodiversity of marine plants in an era of climate change: some predictions based on physiological performance. Bot Mar 41: 113-123

Bell J, Batty M, Ganachaud A, Gehrke P and others (2009) Preliminary assessment of the effects of climate change on fisheries and aquaculture in the Pacific. In: Gillett $R$ (ed) Fisheries in the economies of the Pacific Island countries and territories Pacific Studies Series. Asian Development Bank, Manila, p 451-469

Beveridge MCM, Dabbadie L, Soto D, Ross LG, Bueno PB, Aguilar-Manjarrez J (2018) Climate change and aquaculture: interactions with fisheries and agriculture. In: Barange M, Bahri T, Beveridge MCM, Cochrane KL, Funge-Smith S, Poulain F (eds) Impacts of climate change on fisheries and aquaculture: synthesis of current knowledge, adaptation and mitigation options. Fish Aquacult Tech Pap 627. FAO, Rome, p 491-500

Binh MN, Van An L, Thuy NTT, Giang NTh, Hoai HTT, Van Dan T (2017) Impact of climate change on aquaculture in Phu Vang District, Thua Thien Hue Province, Vietnam. Agriculture and Development Discussion Paper Series 2017-3. Southeast Asian Regional Center for Graduate Study and Research in Agriculture (SEARCA), Los Baños

Boero F, Kraberg AC, Krause G, Wiltshire KH (2015) Time is an affliction: why ecology cannot be as predictive as physics and why it needs time series. J Sea Res 101: 12-18

Bondad-Reantaso MG, Garrido-Gamarro E, McGladder SE (2018) Climate change-driven hazards on food safety and aquatic animal health. In: Barange $M$, Bahri T, Beveridge MCM, Cochrane KL, Funge-Smith S, Poulain F (eds) Impacts of climate change on fisheries and aquaculture: synthesis of current knowledge, adaptation and mitigation options. Fish Aquacult Tech Pap 627. FAO, Rome, p 517-534

* Bopp L, Resplandy L, Orr JC, Doney SC and others (2013) Multiple stressors of ocean ecosystems in the 21st century: projections with CMIP5 models. Biogeosciences 10: 6225-6245

Borges AV, Gypens N (2010) Carbonate chemistry in the coastal zone responds more strongly to eutrophication than to ocean acidification. Limnol Oceanogr 55:346-353

Bosma RH, Hakim LL, Groeneveld RA (2017) Investing in climate change mitigation and adaptation on mangrove and aquaculture doubles benefits. The 3rd International Conference on Tropical and Coastal Region Eco-Development (ICTCRED 2017), Yogjakarta

Bostock J, Lane A, Hough C, Yamamoto K (2016) An assessment of the economic contribution of EU aquaculture production and the influence of policies for its sustainable development. Aquacult Int 24:699-733
Bowden TJ, Thompson KD, Morgan AL, Gratacap RML, Nikoskelainen S (2007) Seasonal variation and the immune response: a fish perspective. Fish Shellfish Immunol 22:695-706

Boyd PW (2013) Framing biological responses to a changing ocean. Nat Clim Change 3:530-533

* Boyd PW, Hutchins DA (2012) Understanding the responses of ocean biota to a complex matrix of cumulative anthropogenic change. Mar Ecol Prog Ser 470:125-135

Boyd PW, Lennartz ST, Glover DM, Doney SC (2015) Biological ramifications of climate-change-mediated oceanic multi-stressors. Nat Clim Change 5:71-79

Boyd PW, Cornwall CE, Davison A, Doney SC and others (2016) Biological responses to environmental heterogeneity under future ocean conditions. Glob Change Biol 22:2633-2650

Boyd R, Stern N, Ward B (2015) What will global annual emissions of greenhouse gases be in 2030, and will they be consistent with avoiding global warming of more than $2^{\circ} \mathrm{C}$ ? Policy paper. ESRC Centre for Climate Change Economics and Policy, Grantham Research Institute on Climate Change and the Environment. http://www.lse. ac.uk/GranthamInstitute/wp-content/uploads/2015/05/ Boyd_et_al_policy_paper_May_2015.pdf

*Bennan G, Collins S (2015) Growth responses of a green alga to multiple environmental drivers. Nat Clim Change 5:892-897

* Bresolin De Souza K, Jutfelt F, Kling P, Förlin L, Sturve J (2014) Effects of increased $\mathrm{CO}_{2}$ on fish gill and plasma proteome. PLOS ONE 9:e102901

* Brigolin D, Lourguioui H, Taji MA, Venier C, Mangin A, Pastres R (2015) Space allocation for coastal aquaculture in North Africa: data constraints, industry requirements and conservation issues. Ocean Coast Manag 116:89-97

Britz PJ, Hecht T, Mangold S (1997) Effect of temperature on growth, feed consumption and nutritional indices of Haliotis midae fed a formulated diet. Aquaculture 152: 191-203

* Broch OJ, Ellingsen IH, Forbord S, Wang X and others (2013) Modelling the cultivation and bioremediation potential of the kelp Saccharina latissima in close proximity to an exposed salmon farm in Norway. Aquacult Environ Interact 4:187-206

Brugère C (2015) Climate change vulnerability in fisheries and aquaculture: a synthesis of six regional studies. FAO Fisheries Circular. FAO, Rome

* Brugere C, Onuigbo DM, Morgan KL (2017) People matter in animal disease surveillance: challenges and opportunities for the aquaculture sector. Aquaculture 467: 158-169

* Buchheister A, Miller TJ, Houde ED, Secor DH, Latour RJ (2016) Spatial and temporal dynamics of Atlantic menhaden (Brevoortia tyrannus) recruitment in the Northwest Atlantic Ocean. ICES J Mar Sci 73:1147-1159

* Buchtíková S, Šimková A, Rohlenová K, Flajšhans M, Lojek A, Lilius EM, Hyršl P (2011) The seasonal changes in innate immunity of the common carp (Cyprinus carpio). Aquaculture 318:169-175

* Bunlipatanon P, Songseechan N, Kongkeo H, Abery NW, De Silva SS (2014) Comparative efficacy of trash fish versus compounded commercial feeds in cage aquaculture of Asian seabass (Lates calcarifer) (Bloch) and tiger grouper (Epinephelus fuscoguttatus) (Forsskål). Aquacult Res 45: 373-388 
Burge CA, Eakin CM, Friedman CS, Froelich B and others (2014) Climate change influences on marine infectious diseases: implications for management and society. Annu Rev Mar Sci 6:249-277

Byrne M, Ho M, Selvakumaraswamy P, Nguyen HD, Dworjanyn SA, Davis AR (2009) Temperature, but not $\mathrm{pH}$, compromises sea urchin fertilization and early development under near-future climate change scenarios. Proc R Soc B 276:1883-1888

Byrne M, Foo S, Soars NA, Wolfe KDL, Nguyen HD, Hardy N, Dworjanyn SA (2013) Ocean warming will mitigate the effects of acidification on calcifying sea urchin larvae (Heliocidaris tuberculata) from the Australian global warming hot spot. J Exp Mar Biol Ecol 448:250-257

Cai W, Borlace S, Lengaigne M, van Rensch P and others (2014) Increasing frequency of extreme El Niño events due to greenhouse warming. Nat Clim Change 4: $111-116$

Cai W, Wang G, Santoso A, McPhaden MJ and others (2015) Increased frequency of extreme La Niña events under greenhouse warming. Nat Clim Change 5:132-137

* Caldeira K, Wickett ME (2003) Anthropogenic carbon and ocean $\mathrm{pH}$. Nature 425:365

Can NV, Tuan PA (2012) Marine fish farming in Vietnam: Submergible cage design could support offshore culture. Global Aquaculture Advocate July/August 2012:67-68

* Catalán IA, Auch D, Kamermans P, Morales-Nin B and others (2019) Critically examining the knowledge base required to mechanistically project climate impacts: a case study of Europe's fish and shellfish. Fish Fish 20: 501-517

* Chadwick R, Good P, Martin G, Rowell DP (2016) Large rainfall changes consistently projected over substantial areas of tropical land. Nat Clim Change 6:177-181

Chambers LE, Barnard P, Poloczanska ES, Hobday AJ, Keatley MR, Allsopp N, Underhill LG (2017) Southern Hemisphere biodiversity and global change: data gaps and strategies. Austral Ecol 42:20-30

Chang HK, Tsung SC, Lai JS, Tan YC (2013) Regional drainage characteristics and overflow prevention in a fish farm area. J Taiwan Agric Eng 59:15-25

Chiaramonte L, Munson D, Trushenski J (2016) Climate change and considerations for fish health and fish health professionals. Fisheries 41:396-399

Chivers DP, McCormick MI, Nilsson GE, Munday PL and others (2014) Impaired learning of predators and lower prey survival under elevated $\mathrm{CO}_{2}$ : a consequence of neurotransmitter interference. Glob Change Biol 20: 515-522

Choi HG, Kim YS, Kim JH, Lee SJ, Park EJ, Ryu J, Nam KW (2006) Effects of temperature and salinity on the growth of Gracilaria verrucosa and G. chorda, with the potential for mariculture in Korea. J Appl Phycol 18:269-277

Chopin T, Cooper JA, Reid G, Cross S, Moore C (2012) Open-water integrated multi-trophic aquaculture: environmental biomitigation and economic diversification of fed aquaculture by extractive aquaculture. Rev Aquacult $4: 209-220$

Chow J (2018) Mangrove management for climate change adaptation and sustainable development in coastal zones. J Sustain For 37:139-156

* Chowdhury MAK, Siddiqui S, Hua K, Bureau DP (2013) Bioenergetics-based factorial model to determine feed requirement and waste output of tilapia produced under commercial conditions. Aquaculture 410-411:138-147
Chung WS, Marshall NJ, Watson SA, Munday PL, Nilsson GE (2014) Ocean acidification slows retinal function in a damselfish through interference with GABAA receptors. J Exp Biol 217:323-326

Church JA, Hunter JR, McInnes KL, White NJ (2006) Sealevel rise around the Australian coastline and the changing frequency of extreme sea-level events. Aust Meteorol Mag 55:253-260

* Cinner JE, Adger WN, Allison EH, Barnes ML and others (2018) Building adaptive capacity to climate change in tropical coastal communities. Nat Clim Change 8: 117-123

* Clements JC, Chopin T (2017) Ocean acidification and marine aquaculture in North America: potential impacts and mitigation strategies. Rev Aquacult 9:326-341

Cornelisen CD, Gillespie PA, Kirs M, Young RG and others (2011) Motueka River plume facilitates transport of ruminant faecal contaminants into shellfish growing waters, Tasman Bay, New Zealand. NZ J Mar Freshw Res 45: 477-495

Cornwall CE, Hurd CL (2016) Experimental design in ocean acidification research: problems and solutions. ICES J Mar Sci 73:572-581

Craig RC (2015) Re-tooling marine food supply resilience in a climate change era: some needed reforms. Seattle Univ Law Rev 38:1189-1235

* Dapueto G, Massa F, Costa S, Cimoli L and others (2015) A spatial multi-criteria evaluation for site selection of offshore marine fish farm in the Ligurian Sea, Italy. Ocean Coast Manag 116:64-77

DEE (Department of the Environment and Energy) (2015) National climate resilience and adaptation strategy. Australian Government, Department of the Environment and Energy, Canberra

de Melo CMR, Durland E, Langdon C (2016) Improvements in desirable traits of the Pacific oyster, Crassostrea gigas, as a result of five generations of selection on the West Coast, USA. Aquaculture 460:105-115

* De Silva SS (2016) Culture based fisheries in Asia are a strategy to augment food security. Food Secur 8:585-596

De Silva SS, Soto D (2009) Climate change and aquaculture: potential impacts, adaptation and mitigation. In: Cochrane K, De Young C, Soto D, Bahri T (eds) Climate change implications for fisheries and aquaculture: overview of current scientific knowledge. Fish Aquacult Tech Pap 530. FAO, Rome, p 151-212

DePasquale E, Baumann H, Gobler CJ (2015) Vulnerability of early life stage Northwest Atlantic forage fish to ocean acidification and low oxygen. Mar Ecol Prog Ser 523: 145-156

Dessai S, Hulme M, Lempert R, Pielke RJ (2009) Climate prediction: a limit to adaptation? In: Adger W, Lorenzoni I, O'Brien K (eds) Adapting to climate change: thresholds, values, governance. Cambridge University Press, Cambridge, p 64-78

* Díaz RJ, Rosenberg R, Rabalais NN, Levin LA (2009) Dead zone dilemma. Mar Pollut Bull 58:1767-1768

Dodd Q (2011) Staff and volunteers battle flood waters to save stock at North Carolina facility. Aquaculture North America 2(6):18

* Doney SC (2006) Plankton in a warmer world. Nature 444: 695-696

* Doney SC, Fabry VJ, Feely RA, Kleypas JA (2009) Ocean acidification: the other $\mathrm{CO}_{2}$ problem. Annu Rev Mar Sci $1: 169-192$ 
Doney SC, Ruckelshaus M, Duffy JE, Barry JP and others (2012) Climate change impacts on marine ecosystems. Annu Rev Mar Sci 4:11-37

* Dove MC, Sammut J (2007) Impacts of estuarine acidification on survival and growth of Sydney rock oysters Saccostrea glomerata (Gould 1850). J Shellfish Res 26: 519-527

Duarte CM, Wu J, Xiao X, Bruhn A, Krause-Jensen D (2017) Can seaweed farming play a role in climate change mitigation and adaptation? Front Mar Sci 4:100

Dubey SK, Trivedi RK, Chand BK, Mandal B, Rout SK (2017) Farmers' perceptions of climate change, impacts on freshwater aquaculture and adaptation strategies in climatic change hotspots: a case of the Indian Sundarban delta. Environ Dev 21:38-51

Ekstrom JA, Suatoni L, Cooley SR, Pendleton LH and others (2015) Vulnerability and adaptation of US shellfisheries to ocean acidification. Nat Clim Change 5:207-214

Ellis RP, Urbina MA, Wilson RW (2017) Lessons from two high $\mathrm{CO}_{2}$ worlds - future oceans and intensive aquaculture. Glob Change Biol 23:2141-2148

Engle CR (2016) Why interdisciplinary research is critical for the growth and development of aquaculture. J World Aquacult Soc 47:149-151

FAO (2014) The state of world fisheries and aquaculture: opportunities and challenges. Rep 1020-5489. FAO, Rome

FAO (2015) Report of the APFIC/FAO Regional Consultation: improving the contribution of culture-based fisheries and fishery enhancements in inland waters to Blue Growth. FAO, Rome

FAO (2016) The state of the world fisheries and aquaculture 2016: contributing to food security and nutrition for all. FAO, Rome

FAO (2018) The state of world fisheries and aquaculture 2018: meeting the sustainable development goals. FAO, Rome

Fasullo JT, Otto-Bliesner BL, Stevenson S (2018) ENSO's changing influence on temperature, precipitation, and wildfire in a warming climate. Geophys Res Lett 45: 9216-9225

Fitzgerald-Dehoog L, Browning J, Allen BJ (2012) Food and heat stress in the California mussel: evidence for an energetic trade-off between survival and growth. Biol Bull (Woods Hole) 223:205-216

Fransen T, Nakhooda S, McGray H (2009) Comparative analysis of national climate change strategies in developing countries. World Resources Institute, Washington, DC

Friedrich T, Timmermann A, Abe-Ouchi A, Bates NR and others (2012) Detecting regional anthropogenic trends in ocean acidification against natural variability. Nat Clim Change 2:167-171

Friess DA, Lee SY, Primavera JH (2016) Turning the tide on mangrove loss. Mar Pollut Bull 109:673-675

Fry FEJ, Hart JS (1948) The relation of temperature to oxygen consumption in the goldfish. Biol Bull (Woods Hole) 94:66-77

Fry JP, Love DC, MacDonald GK, West PC, Engstrom PM, Nachman KE, Lawrence RS (2016) Environmental health impacts of feeding crops to farmed fish. Environ Int 91: 201-214

Gazeau F, Parker LM, Comeau S, Gattuso JP and others (2013) Impacts of ocean acidification on marine shelled molluscs. Mar Biol 160:2207-2245
Giron-Nava A, James CC, Johnson AF, Dannecker D and others (2017) Quantitative argument for long-term ecological monitoring. Mar Ecol Prog Ser 572:269-274

Glencross BD, Bermudes M (2012) Adapting bioenergetic factorial modelling to understand the implications of heat stress on barramundi (Lates calcarifer) growth, feed utilisation and optimal protein and energy requirements potential strategies for dealing with climate change? Aquacult Nutr 18:411-422

* Gobler CJ, DePasquale EL, Griffith AW, Baumann H (2014) Hypoxia and acidification have additive and synergistic negative effects on the growth, survival, and metamorphosis of early life stage bivalves. PLOS ONE 9:e83648

Graiff A, Bartsch I, Ruth W, Wahl M, Karsten U (2015) Season exerts differential effects of ocean acidification and warming on growth and carbon metabolism of the seaweed Fucus vesiculosus in the western Baltic Sea. Front Mar Sci 2:112

Gräns A, Jutfelt F, Sandblom E, Jönsson E and others (2014) Aerobic scope fails to explain the detrimental effects on growth resulting from warming and elevated $\mathrm{CO}_{2}$ in Atlantic halibut. J Exp Biol 217:711-717

* Green MA, Waldbusser GG, Reilly SL, Emerson K, O'Donnell S (2009) Death by dissolution: sediment saturation state as a mortality factor for juvenile bivalves. Limnol Oceanogr 54:1037-1047

* Groner ML, Gettinby G, Stormoen M, Revie CW, Cox R (2014) Modelling the impact of temperature-induced life history plasticity and mate limitation on the epidemic potential of a marine ectoparasite. PLOS ONE 9:e88465

* Groner ML, Maynard J, Breyta R, Carnegie RB and others (2016) Managing marine disease emergencies in an era of rapid change. Philos Trans R Soc B 371:20150364

* Gurney-Smith HJ, Wade AJ, Abbott CL (2017) Species composition and genetic diversity of farmed mussels in British Columbia, Canada. Aquaculture 466:33-40

Hall GM (2015) Impact of climate change on aquaculture: the need for alternative feed components. Turk J Fish Aquat Sci 15:569-574

* Hallegraeff GM (2010) Ocean climate change, phytoplankton community responses, and harmful algal blooms: a formidable predictive challenge. J Phycol 46:220-235

*Hamilton TJ, Holcombe A, Tresguerres M (2014) $\mathrm{CO}_{2}$ induced ocean acidification increases anxiety in rockfish via alteration of GABAA receptor functioning. Proc R Soc B 281:20132509

* Han T, Jiang Z, Fang J, Zhang J and others (2013) Carbon dioxide fixation by the seaweed Gracilaria lemaneiformis in integrated multi-trophic aquaculture with the scallop Chlamys farreri in Sanggou Bay, China. Aquacult Int 21:1035-1043

Handisyde N, Salam MA, Ross LG (2008) Spatial aspects of climate change and effects on aquaculture in Bangladesh. 29th Asian Conference on Remote Sensing 2008, Colombo, Vol 2. Elsevier, Amsterdam, p 848-854

Handisyde N, Lacalle DS, Arranz S, Ross LG (2014) Modelling the flood cycle, aquaculture development potential and risk using MODIS data: a case study for the floodplain of the Rio Paraná, Argentina. Aquaculture 422423:18-24

Hargreaves JA (2014) Editor's note: Climate change is here now. Aquacult Mag 45:3

*Harley CDG, Hughes AR, Hultgren KM, Miner BG and others (2006) The impacts of climate change in coastal marine systems. Ecol Lett 9:228-241 
Harris W (2015) Sea lice decision support system being tested in Newfoundland. Aquaculture North America. Capamara Communications. https://www.aquaculturenorth america.com/sea-lice-decision-support-system-beingtested-in-newfoundlan-1473/

Hauber ME, Bierbach D, Linsenmair KE (2011) The traditional Whedo aquaculture system in northern Benin. J Appl Aquacult 23:67-84

*Haunschild R, Bornmann L, Marx W (2016) Climate change research in view of bibliometrics. PLOS ONE 11: e0160393

*Hay CC, Morrow E, Kopp RE, Mitrovica JX (2015) Probabilistic reanalysis of twentieth-century sea-level rise. Nature 517:481-484

*Hellicar AD, Rahman A, Smith DV, Smith G, McCulloch J, Andrewartha S, Morash A (2015) An algorithm for the automatic analysis of signals from an oyster heart rate sensor. IEEE Sensors J 15:4480-4487

* Hirabayashi Y, Mahendran R, Koirala S, Konoshima L and others (2013) Global flood risk under climate change. Nat Clim Change 3:816-821

* Hixson SM, Arts MT (2016) Climate warming is predicted to reduce omega-3, long-chain, polyunsaturated fatty acid production in phytoplankton. Glob Change Biol 22: 2744-2755

Hobday AJ, Spillman CM, Eveson JP, Hartog JR, Zhang X, Brodie S (2018) A framework for combining seasonal forecasts and climate projections to aid risk management for fisheries and aquaculture. Front Mar Sci 5:137

* Hori TS, Gamperl AK, Nash G, Booman M, Barat A, Rise ML (2013) The impact of a moderate chronic temperature increase on spleen immune-relevant gene transcription depends on whether Atlantic cod (Gadus morhua) are stimulated with bacterial versus viral antigens. Genome 56:567-576

Hossain MS, Das NG (2010) GIS-based multi-criteria evaluation to land suitability modelling for giant prawn (Macrobrachium rosenbergii) farming in Companigonj Upazila of Noakhali, Bangladesh. Comput Electron Agric 70: 172-186

Hossain MS, Chowdhury SR, Das NG, Rahaman MM (2007) Multi-criteria evaluation approach to GIS-based landsuitability classification for tilapia farming in Bangladesh. Aquacult Int 15:425-443

Howes E, Joos F, Eakin M, Gattuso JP (2015) An updated synthesis of the observed and projected impacts of climate change on the chemical, physical and biological processes in the oceans. Front Mar Sci 2:36

Hua K, Bureau DP (2009) Development of a model to estimate digestible lipid content of salmonid fish feeds. Aquaculture 286:271-276

Huang JF, Xu QY, Chang YM (2015) Effects of temperature and dietary protein on gene expression of $H s p 70$ and Wap65 and immunity of juvenile mirror carp (Cyprinus carpio). Aquacult Res 46:2776-2788

Huguet CT, Norambuena F, Emery JA, Hermon K, Turchini GM (2015) Dietary n-6/n-3 LC-PUFA ratio, temperature and time interactions on nutrients and fatty acids digestibility in Atlantic salmon. Aquaculture 436:160-166

* Hulata G (2001) Genetic manipulations in aquaculture: a review of stock improvement by classical and modern technologies. Genetica 111:155-173

Humphreys MP (2017) Climate sensitivity and the rate of ocean acidification: future impacts, and implications for experimental design. ICES J Mar Sci 74:934-940
Hurd CL (2015) Slow-flow habitats as refugia for coastal calcifiers from ocean acidification. J Phycol 51:599-605

Idris K, Azman A, D'Silva JL, Man N, Shaffril HAM (2014) Environmental challenges on aquaculture rearing in Malaysia: the views of brackish-water cage entrepreneurs in Malaysia. Life Sci J 11:509-513

FIFAD (International Fund for Agricultural Development) (2014) Guidelines for integrating climate change adaptation into fisheries and aquaculture projects. https://www. ifad.org/documents/38714170/39135645/fisheries.pdf

IPCC (2007) Climate Change 2007: the physical science basis. Contribution of Working Group I to the Fourth Assessment Report of the Intergovernmental Panel on Climate Change. Cambridge University Press, Cambridge

Iwama GK, Tautz AF (1981) A simple growth model for salmonids in hatcheries. Can J Fish Aquat Sci 38: 649-656

James N (2016) Red tape strangles SA aquaculture. www.farmersweekly.co.za/animals/aquaculture/red-tapestrangles-sa-aquaculture/ (accessed 30 March 2017)

Jensen Ø, Dempster T, Thorstad EB, Uglem I, Fredheim A (2010) Escapes of fishes from Norwegian sea-cage aquaculture: causes, consequences and prevention. Aquacult Environ Interact 1:71-83

Kais SM, Islam MS (2018) Impacts of and resilience to climate change at the bottom of the shrimp commodity chain in Bangladesh: a preliminary investigation. Aquaculture 493:406-415

Kelly MW, Padilla-Gamiño JL, Hofmann GE (2013) Natural variation and the capacity to adapt to ocean acidification in the keystone sea urchin Strongylocentrotus purpuratus. Glob Change Biol 19:2536-2546

Kemp WM, Boynton WR, Adolf JE, Boesch DF and others (2005) Eutrophication of Chesapeake Bay: historical trends and ecological interactions. Mar Ecol Prog Ser 303:1-29

Khan AS, Ramachandran A, Usha N, Punitha S, Selvam V (2012) Predicted impact of the sea-level rise at VellarColeroon estuarine region of Tamil Nadu coast in India: mainstreaming adaptation as a coastal zone management option. Ocean Coast Manag 69:327-339

Khan JR, Pether S, Bruce M, Walker SP, Herbert NA (2014) Optimum temperatures for growth and feed conversion in cultured hapuku (Polyprion oxygeneios) - Is there a link to aerobic metabolic scope and final temperature preference? Aquaculture 430:107-113

Kim T, Lee J, Fredriksson DW, DeCew J, Drach A, Moon K (2014) Engineering analysis of a submersible abalone aquaculture cage system for deployment in exposed marine environments. Aquacult Eng 63:72-88

Kipkemboi J, Kilonzi CM, van Dam AA, Kitaka N, Mathooko JM, Denny P (2010) Enhancing the fish production potential of Lake Victoria papyrus wetlands, Kenya, using seasonal flood-dependent ponds. Wetlands Ecol Manag 18:471-483

Kroeker KJ, Kordas RL, Crim RN, Singh GG (2010) Metaanalysis reveals negative yet variable effects of ocean acidification on marine organisms. Ecol Lett 13: 1419-1434

Kroeker KJ, Gaylord B, Hill TM, Hosfelt JD, Miller SH, Sanford E (2014) The role of temperature in determining species' vulnerability to ocean acidification: a case study using Mytilus galloprovincialis. PLOS ONE 9: e100353 
Kurihara H, Kato S, Ishimatsu A (2007) Effects of increased seawater $\mathrm{pCO}_{2}$ on early development of the oyster Crassostrea gigas. Aquat Biol 1:91-98

Lafferty KD (2009) The ecology of climate change and infectious diseases. Ecology 90:888-900

Kafferty KD, Harvell CD, Conrad JM, Friedman CS and others (2015) Infectious diseases affect marine fisheries and aquaculture economics. Annu Rev Mar Sci 7: 471-496

Lange B, Currie KL, Howarth GS, Stone DAJ (2014) Grape seed extract and dried macroalgae, Ulva lactuca Linnaeus, improve survival of greenlip abalone, Haliotis laevigata Donovan, at high water temperature. Aquaculture 433:348-360

Lawrence C (2016) Substantial damage at WSS fish hatchery after floods. http://wvmetronews.com/2016/07/06/ substantial-damage-at-wss-fish-hatchery-after-floods/ (accessed 1 November 2016)

Lefevre S, Wang T, Jensen A, Cong NV, Huong DTT, Phuong NT, Bayley M (2014) Air-breathing fishes in aquaculture. What can we learn from physiology? J Fish Biol 84:705-731

Leung TLF, Bates AE (2013) More rapid and severe disease outbreaks for aquaculture at the tropics: implications for food security. J Appl Ecol 50:215-222

Liew SC, Raghavan SV, Liong SY (2014) How to construct future IDF curves, under changing climate, for sites with scarce rainfall records? Hydrol Process 28:3276-3287

* Lindegren M, Checkley DM, Rouyer T, MacCall AD, Stenseth NC (2013) Climate, fishing, and fluctuations of sardine and anchovy in the California Current. Proc Natl Acad Sci USA 110:13672-13677

Lomborg B (2016) Impact of current climate proposals. Glob Policy 7:109-118

Lorenzen K, Ainsworth CH, Baker SM, Barbieri LR, Camp EV, Dotson JR, Lester SE (2017) Climate change impacts on Florida's fisheries and aquaculture sectors and options for adaptation. In: Chassignet EP, Jones JW, Misra V, Obeysekera J (eds) Florida's climate: changes, variations, \& impacts. Florida Climate Institute, Gainesville, FL, p 427-455

Luening E (2013) After the hurricane. Aquaculture North America 4(2):1

Mamat N, Rasam ARA, Adnan NA, Abdullah IC (2014) GISbased multi-criteria decision making system for determining potential site of oyster aquaculture in Terengganu. Proceedings - 2014 IEEE 10th International Colloquium on Signal Processing and Its Applications, Kuala Lumpur, p 71-76

* Mangan S, Urbina MA, Findlay HS, Wilson RW, Lewis C (2017) Fluctuating seawater $\mathrm{pH} / \mathrm{CO}_{2}$ regimes are more energetically expensive than static $\mathrm{pH} / \mathrm{CO}_{2}$ levels in the mussel Mytilus edulis. Proc R Soc B 284:20171642

* Martinez M, Mangano MC, Maricchiolo G, Genovese L, Mazzola A, Sarà G (2018) Measuring the effects of temperature rise on Mediterranean shellfish aquaculture. Ecol Indic 88:71-78

* Matozzo V, Chinellato A, Munari M, Finos L, Bressan M, Marin MG (2012) First evidence of immunomodulation in bivalves under seawater acidification and increased temperature. PLOS ONE 7:e33820

McCoy D, McManus MA, Kotubetey K, Kawelo AH and others (2017) Large-scale climatic effects on traditional Hawaiian fishpond aquaculture. PLOS ONE 12: $\mathrm{e} 0187951$
Melzner F, Stange $\mathrm{P}$, Trübenbach $\mathrm{K}$, Thomsen J and others (2011) Food supply and seawater $p \mathrm{CO}_{2}$ impact calcification and internal shell dissolution in the blue mussel Mytilus edulis. PLOS ONE 6:e24223

* Merino G, Barange M, Mullon C (2010) Climate variability and change scenarios for a marine commodity: modelling small pelagic fish, fisheries and fishmeal in a globalized market. J Mar Syst 81:196-205

* Miller AW, Reynolds AC, Sobrino C, Riedel GF (2009) Shellfish face uncertain future in high $\mathrm{CO}_{2}$ world: influence of acidification on oyster larvae calcification and growth in estuaries. PLOS ONE 4:e5661

Miller GM, Kroon FJ, Metcalfe S, Munday PL (2015) Temperature is the evil twin: effects of increased temperature and ocean acidification on reproduction in a reef fish. Ecol Appl 25:603-620

* Miller SH, Breitburg DL, Burrell RB, Keppel AG (2016) Acidification increases sensitivity to hypoxia in important forage fishes. Mar Ecol Prog Ser 549:1-8

*Nath SS, Bolte JP, Ross LG, Aguilar-Manjarrez J (2000) Applications of geographical information systems (GIS) for spatial decision support in aquaculture. Aquacult Eng 23:233-278

*Nouyen AL, Dang VH, Bosma RH, Verreth JAJ, Leemans R, De Silva SS (2014) Simulated impacts of climate change on current farming locations of striped catfish (Pangasianodon hypophthalmus; Sauvage) in the Mekong Delta, Vietnam. Ambio 43:1059-1068

Nguyen AL, Truong MH, Verreth JA, Leemans R, Bosma RH, De Silva SS (2015) Exploring the climate change concerns of striped catfish producers in the Mekong Delta, Vietnam. Springerplus 4:46

Nguyen LA, Verreth JAJ, Leemans R, Bosma R, De Silva S (2016) A decision tree analysis to support potential climate change adaptations of striped catfish (Pangasianodon hypophthalmus Sauvage) farming in the Mekong Delta, Vietnam. Tropicultura 34:105-115

Nguyen NH (2016) Genetic improvement for important farmed aquaculture species with a reference to carp, tilapia and prawns in Asia: achievements, lessons and challenges. Fish Fish 17:483-506

Nilsson GE, Dixson DL, Domenici P, McCormick MI, Sorensen C, Watson SA, Munday PL (2012) Near-future carbon dioxide levels alter fish behaviour by interfering with neurotransmitter function. Nat Clim Change 2: 201-204

Olsen RL, Hasan MR (2012) A limited supply of fishmeal: impact on future increases in global aquaculture production. Trends Food Sci Technol 27:120-128

\% Orr JC, Fabry VJ, Aumont O, Bopp L and others (2005) Anthropogenic ocean acidification over the twenty-first century and its impact on calcifying organisms. Nature 437:681-686

Ottinger M, Clauss K, Kuenzer C (2016) Aquaculture: relevance, distribution, impacts and spatial assessments - a review. Ocean Coast Manag 119:244-266

Oyebola OO, Olatunde OM (2019) Climate change adaptation through aquaculture: ecological considerations and regulatory requirements for tropical Africa. In: Bamutaze Y, Kyamanywa S, Singh BR, Nabanoga G, Lal R (eds) Agriculture and ecosystem resilience in Sub Saharan Africa. Springer, Cham, p 435-472

* Pankhurst NW, Munday PL (2011) Effects of climate change on fish reproduction and early life history stages. Mar Freshw Res 62:1015-1026 
Paprocki K, Huq S (2018) Shrimp and coastal adaptation: on the politics of climate justice. Clim Dev 10:1-3

'Parker LM, Ross PM, O'Connor WA (2011) Populations of the Sydney rock oyster, Saccostrea glomerata, vary in response to ocean acidification. Mar Biol 158: 689-697

* Parker LM, Ross PM, O'Connor WA, Pörtner HO, Scanes E, Wright JM (2013) Predicting the response of molluscs to the impact of ocean acidification. Biology (Basel) 2: 651-692

Pauly D, Zeller D (2016) Catch reconstructions reveal that global marine fisheries catches are higher than reported and declining. Nat Commun 7:10244

* Pedersen MW, Kokkalis A, Bardarson H, Bonanomi S and others (2016) Trends in marine climate change research in the Nordic region since the first IPCC report. Clim Change 134:147-161

Peeler EJ, Feist SW (2011) Human intervention in freshwater ecosystems drives disease emergence. Freshw Biol 56:705-716

Perez OM, Telfer TC, Ross LG (2005) Geographical information systems-based models for offshore floating marine fish cage aquaculture site selection in Tenerife, Canary Islands. Aquacult Res 36:946-961

Pickering TD, Ponia B, Hair CA, Southgate P and others (2011) Vulnerability of aquaculture in the tropical Pacific to climate change. In: Bell JD, Johnson JE, Hobday AJ (eds) Vulnerability of tropical pacific fisheries and aquaculture to climate change. Secretariat of the Pacific Community, Noumea, p 647-731

Pittman K, Yúfera M, Pavlidis M, Geffen AJ and others (2013) Fantastically plastic: fish larvae equipped for a new world. Rev Aquacult 5:S224-S267

Pörtner HO (2008) Ecosystem effects of ocean acidification in times of ocean warming: a physiologist's view. Mar Ecol Prog Ser 373:203-217

Radiarta IN, Saitoh SI, Miyazono A (2008) GIS-based multicriteria evaluation models for identifying suitable sites for Japanese scallop (Mizuhopecten yessoensis) aquaculture in Funka Bay, southwestern Hokkaido, Japan. Aquaculture 284:127-135

Rahman MM, Hossain MS (2012) Mangrove forests and aquaculture farmers: aspects of climate change adaptation on the central coast of Bangladesh. Aquacult Mag 43:12-17

Rahmani V, Hutchinson SL, Harrington JA, Hutchinson JMS (2016) Analysis of frequency and magnitude of extreme rainfall events with potential impacts on flooding: a case study from the central United States. Int J Climatol 36: 3578-3587

Range P, Chicharo MA, Ben-Hamadou R, Piló D and others (2011) Calcification, growth and mortality of juvenile clams Ruditapes decussatus under increased $\mathrm{pCO}_{2}$ and reduced $\mathrm{pH}$ : variable responses to ocean acidification at local scales? J Exp Mar Biol Ecol 396:177-184

Ray DK, Mueller ND, West PC, Foley JA (2013) Yield trends are insufficient to double global crop production by 2050 . PLOS ONE 8:e66428

Reid GK, Gurney-Smith HJ (eds) (2016) Proceedings of the Atlantic and Pacific Climate Change and Aquaculture Workshops. Bull Aquacult Assoc Canada 2015-2. Aquaculture Association of Canada, St. Andrews

Reid GK, Jackson T (2014) Climate change sessions increasingly prominent at aquaculture meetings. Aquacult Mag 45:9-10
Reid GK, Chopin T, Robinson SMC, Azevedo P, Quinton M, Belyea E (2013) Weight ratios of the kelps, Alaria esculenta and Saccharina latissima, required to sequester dissolved inorganic nutrients and supply oxygen for Atlantic salmon, Salmo salar, in Integrated Multi-Trophic Aquaculture systems. Aquaculture 408-409:34-46

Reid GK, Filgueira R, Garber A (2015) Revisiting temperature effects on aquaculture in light of pending climate change. In: Wade J, Jackson T, Brewer-Dalton K (eds) Aquaculture Canada 2014. Aquaculture Association of Canada, St. Andrews, p 85-91

* Remen M, Oppedal F, Imsland AK, Olsen RE, Torgersen T (2013) Hypoxia tolerance thresholds for post-smolt Atlantic salmon: dependency of temperature and hypoxia acclimation. Aquaculture 416-417:41-47

Remen M, Sievers M, Torgersen T, Oppedal F (2016) The oxygen threshold for maximal feed intake of Atlantic salmon post-smolts is highly temperature-dependent. Aquaculture 464:582-592

* Reum JCP, Alin SR, Harvey CJ, Bednaršek N and others (2016) Interpretation and design of ocean acidification experiments in upwelling systems in the context of carbonate chemistry co-variation with temperature and oxygen. ICES J Mar Sci 73:582-595

Rhein M, Rintoul SR, Aoki S, Campos E and others (2013) Observations: ocean. In: Stocker TF, Qin D, Plattner GK, Tignor $\mathrm{M}$ and others (eds) Climate change 2013: the physical science basis. Contribution of Working Group I to the Fifth Assessment Report of the Intergovernmental Panel on Climate Change. Cambridge University Press, Cambridge, p 255-316

Kichards RG, Davidson AT, Meynecke JO, Beattie K, Hernaman V, Lynam T, van Putten IE (2015) Effects and mitigations of ocean acidification on wild and aquaculture scallop and prawn fisheries in Queensland, Australia. Fish Res 161:42-56

Riebesell U, Gattuso JP (2015) Lessons learned from ocean acidification research. Nat Clim Chang 5:12-14

Riebesell U, Fabry VJ, Hansson L, Gattuso JPE (2010) Guide to best practices for ocean acidification research and data reporting. Publications Office of the European Union, Luxembourg

Ries JB, Cohen AL, McCorkle DM (2009) Marine calcifiers exhibit mixed responses to $\mathrm{CO}_{2}$-induced ocean acidification. Geology 37:1131-1134

Rogelj J, McCollum DL, O'Neill BC, Riahi K (2013) 2020 emissions levels required to limit warming to below $2{ }^{\circ} \mathrm{C}$. Nature Clim Change 3:405-412

Kohr JR, Dobson AP, Johnson PTJ, Kilpatrick AM and others (2011) Frontiers in climate change-disease research. Trends Ecol Evol 26:270-277

'Sainsbury NC, Genner MJ, Saville GR, Pinnegar JK, O'Neill CK, Simpson SD, Turner RA (2018) Changing storminess and global capture fisheries. Nat Clim Change 8: 655-659

Salisbury J, Green MA, Hunt C, Campbell J (2008) Coastal acidification by rivers: a threat to shellfish? EOS Trans Am Geophys Union 89:513-514

* Sanford E, Kelly MW (2011) Local adaptation in marine invertebrates. Annu Rev Mar Sci 3:509-535

* Sarà G, Mangano MC, Johnson M, Mazzola A (2018) Integrating multiple stressors in aquaculture to build the blue growth in a changing sea. Hydrobiologia 809:5-17

Schmidt D, Boyd PW (2016) Forecast ocean variability. Nature 539:162-163 
Schmidtko S, Stramma L, Visbeck M (2017) Decline in global oceanic oxygen content during the past five decades. Nature 542:335

Šegvić-Bubić T, Boban J, Grubišić L, Trumbić Ž, Radman M, Perčić M, Čož-Rakovac R (2013) Effects of propolis enriched diet on growth performance and plasma biochemical parameters of juvenile European sea bass (Dicentrarchus labrax L.) under acute low-temperature stress. Aquacult Nutr 19:877-885

SEMARNAT-INECC (2016) Mexico's climate change midcentury strategy. Ministry of Environment and Natural Resources (SEMARNAT) and National Institute of Ecology and Climate Change (INECC), Mexico City

Shainee M, Ellingsen H, Leira BJ, Fredheim A (2013) Design theory in offshore fish cage designing. Aquaculture 392395:134-141

Shainee M, Leira BJ, Ellingsen H, Fredheim A (2014) Investigation of a self-submersible SPM cage system in random waves. Aquacult Eng 58:35-44

Shelton C (2014) Climate change adaptation in fisheries and aquaculture - compilation of initial examples. FAO Fisheries and Aquaculture Circular No. 1088. FAO, Rome

Sherwood S, Fu Q (2014) A drier future? Science 343: 737-739

* Siikavuopio SI, James P, Lysne H, Sæther BS, Samuelsen TA, Mortensen A (2012) Effects of size and temperature on growth and feed conversion of juvenile green sea urchin (Strongylocentrotus droebachiensis). Aquaculture 354-355:27-30

Singh D (2016) South Asian monsoon: tug of war on rainfall changes. Nat Clim Change 6:20-22

* Sinha E, Michalak AM, Balaji V (2017) Eutrophication will increase during the 21st century as a result of precipitation changes. Science 357:405-408

Smajgl A, Toan TQ, Nhan DK, Ward J and others (2015) Responding to rising sea levels in the Mekong Delta. Nat Clim Change 5:167-174

Smith MD, Roheim CA, Crowder LB, Halpern BS and others (2010) Sustainability and global seafood. Science 327 : 784-786

Soto D, Ross LG, Handisyde N, Bueno PB and others (2018) Climate change and aquaculture: vulnerability and adaptation options. In: Barange $\mathrm{M}$, Bahri $\mathrm{T}$, Beveridge MCM, Cochrane KL, Funge-Smith S, Poulain F (eds) Impacts of climate change on fisheries and aquaculture: synthesis of current knowledge, adaptation and mitigation options. Fish Aquacult Tech Pap 627. FAO, Rome, p 465-490

Spillman CM, Hobday AJ (2014) Dynamical seasonal ocean forecasts to aid salmon farm management in a climate hotspot. Clim Risk Manag 1:25-38

Steffen W, Persson A, Deutsch L, Zalasiewicz J and others (2011) The Anthropocene: from global change to planetary stewardship. Ambio 40:739-761

Stocker TF, Qin D, Plattner GK, Alexander LV and others (2013) Technical summary. In: Stocker TF, Qin D, Plattner GK, Tignor M and others (eds) Climate change 2013: the physical science basis. Contribution of Working Group I to the Fifth Assessment Report of the Intergovernmental Panel on Climate Change. Cambridge University Press, Cambridge, p 33-131

Stramma L, Oschlies A, Schmidtko S (2012) Mismatch between observed and modeled trends in dissolved upperocean oxygen over the last 50 yr. Biogeosciences 9: 4045-4057
Suckling CC, Clark MS, Richard J, Morley SA, Thorne MAS, Harper EM, Peck LS (2015) Adult acclimation to combined temperature and $\mathrm{pH}$ stressors significantly enhances reproductive outcomes compared to short-term exposures. J Anim Ecol 84:773-784

Sui Y, Kong H, Shang Y, Huang X and others (2016) Effects of short-term hypoxia and seawater acidification on hemocyte responses of the mussel Mytilus coruscus. Mar Pollut Bull 108:46-52

Sun Y, Zhang X, Zwiers FW, Song L and others (2014) Rapid increase in the risk of extreme summer heat in Eastern China. Nat Clim Change 4:1082-1085

*Tacon AGJ, Metian M (2015) Feed matters: satisfying the feed demand of aquaculture. Rev Fish Sci Aquacult 23: $1-10$

Tacon AGJ, Hasan MR, Metian M (2011) Demand and supply of feed ingredients for farmed fish and crustaceans: trends and prospects. FAO Fish Aquacult Tech Pap 564. FAO, Rome

* Talmage SC, Gobler CJ (2011) Effects of elevated temperature and carbon dioxide on the growth and survival of larvae and juveniles of three species of Northwest Atlantic bivalves. PLOS ONE 6:e26941

*Thomsen J, Gutowska MA, Saphörster J, Heinemann A and others (2010) Calcifying invertebrates succeed in a naturally $\mathrm{CO}_{2}$-rich coastal habitat but are threatened by high levels of future acidification. Biogeosciences 7 : 3879-3891

Thomsen J, Casties I, Pansch C, Körtzinger A, Melzner F (2013) Food availability outweighs ocean acidification effects in juvenile Mytilus edulis: laboratory and field experiments. Glob Change Biol 19:1017-1027

* Thomsen J, Stapp LS, Haynert K, Schade H and others (2017) Naturally acidified habitat selects for ocean acidification-tolerant mussels. Sci Adv 3:e1602411

Thrush MA, Murray AG, Brun E, Wallace S, Peeler EJ (2011) The application of risk and disease modelling to emerging freshwater diseases in wild aquatic animals. Freshw Biol 56:658-675

* Tilman D, Fargione J, Wolff B, D'Antonio C and others (2001) Forecasting agriculturally driven global environmental change. Science 292:281

* Timmins-Schiffman E, O'Donnell M, Friedman C, Roberts S (2013) Elevated $\mathrm{pCO}_{2}$ causes developmental delay in early larval Pacific oysters, Crassostrea gigas. Mar Biol 160:1973-1982

Timmons MB, Ebeling JM, Wheaton FW, Summerfelt ST, Vinvi BJ (2002) Recirculating aquaculture systems. Northeastern Regional Aquaculture Center, Ithaca, NY

*Tocher DR (2015) Omega-3 long-chain polyunsaturated fatty acids and aquaculture in perspective. Aquaculture 449:94-107

* Trenberth KE, Marquis M, Zebiak S (2016) The vital need for a climate information system. Nat Clim Change 6:1057

* Tully K, Gedan K, Epanchin-Niell R, Strong A and others (2019) The invisible flood: the chemistry, ecology, and social implications of coastal saltwater intrusion. Bioscience 69:368-378

U Uppanunchai A, Chitmanat C, Lebel L (2018) Mainstreaming climate change adaptation into inland aquaculture policies in Thailand. Clim Policy 18:86-98

van Vliet MTH, Franssen WHP, Yearsley JR, Ludwig F, Haddeland I, Lettenmaier DP, Kabat P (2013) Global river discharge and water temperature under climate change. Glob Environ Change 23:450-464 
Vargas CA, Lagos NA, Lardies MA, Duarte C, and others (2017) Species-specific responses to ocean acidification should account for local adaptation and adaptive plasticity. Nat Ecol Evol 1:84

Vosloo D, van Rensburg L, Vosloo A (2013) Oxidative stress in abalone: the role of temperature, oxygen and l-proline supplementation. Aquaculture 416-417:265-271

Wahl M, Covacha SS, Saderne V, Hiebenthal C, Mueller JD, Pansch C, Sawall Y (2018) Macroalgae may mitigate ocean acidification effects on mussel calcification by increasing $\mathrm{pH}$ and its fluctuations. Limnol Oceanogr 63: $3-21$

Waldbusser GG, Bergschneider H, Green MA (2010) Sizedependent $\mathrm{pH}$ effect on calcification in post-larval hard clam Mercenaria spp. Mar Ecol Prog Ser 417:171-182

Waldbusser GG, Voigt EP, Bergschneider H, Green MA, Newell RIE (2011) Biocalcification in the eastern oyster (Crassostrea virginica) in relation to long-term trends in Chesapeake Bay pH. Estuaries Coasts 34:221-231

Waldbusser GG, Hales B, Langdon CJ, Haley BA and others (2015) Saturation-state sensitivity of marine bivalve larvae to ocean acidification. Nat Clim Change 5:273-280

Wang Q, Cheng L, Liu J, Li Z, Xie S, De Silva SS (2015) Freshwater aquaculture in PR China: trends and prospects. Rev Aquacult 7:283-302

Wang W, Sun J, Liu C, Xue Z (2017) Application of immunostimulants in aquaculture: current knowledge and future perspectives. Aquacult Res 48:1-23

Wang Y, Hu M, Wong WH, Shin PK, Cheung SG (2011) The combined effects of oxygen availability and salinity on physiological responses and scope for growth in the green-lipped mussel Perna viridis. Mar Pollut Bull 63: 255-261

Wassmann R, Hien NX, Hoanh CT, Tuong TP (2004) Sea level rise affecting the Vietnamese Mekong Delta: water elevation in the flood season and implications for rice production. Clim Change 66:89-107

Watson J (2015) Red tape is tying up US push for fish farms, entrepreneurs say. www.ocregister.com/articles/federal693946-waters-aquaculture.html (accessed 30 March 2017)

Welch C (2012) Willapa Bay oyster grower sounds alarm, starts hatchery in Hawaii. www.seattletimes.com/seattle-

Editorial responsibility: Symon Dworjanyn,

Coffs Harbour, New South Wales, Australia news/willapa-bay-oyster-grower-sounds-alarm-startshatchery-in-hawaii/ (accessed 30 March 2017)

Wells ML, Trainer VL (2016) International Scientific Symposium on 'Harmful algal blooms and climate change'. PICES Press 24:16-17

Wikfors GH, Ohno M (2001) Impact of algal research in aquaculture. J Phycol 37:968-974

Wilkinson RJ, Longland R, Woolcott H, Porter MJR (2010) Effect of elevated winter-spring water temperature on sexual maturation in photoperiod manipulated stocks of rainbow trout (Oncorhynchus mykiss). Aquaculture 309: 236-244

World Bank (2013) Fish to 2030: prospects for fisheries and aquaculture. Rep 83177-GLB. World Bank, Washington, DC

Xie B, Qin J, Yang H, Wang X, Wang YH, Li TY (2013) Organic aquaculture in China: a review from a global perspective. Aquaculture 414-415:243-253

Xie J, Hu LL, Tang JJ, Wu X and others (2011) Ecological mechanisms underlying the sustainability of the agricultural heritage rice-fish coculture system. Proc Natl Acad Sci USA 108:E1381-E1387

Xu X, Goswami S, Gulledge J, Wullschleger SD, Thornton PE (2016) Interdisciplinary research in climate and energy sciences. Wiley Interdiscip Rev Energy Environ 5: 49-56

*Ytrestøyl T, Aas TS, Åsgård T (2015) Utilisation of feed resources in production of Atlantic salmon (Salmo salar) in Norway. Aquaculture 448:365-374

Zhai L, Greenan B, Hunter J, James T, Han G, Thomson R, MacAulay P (2014) Estimating sea-level allowances for the coasts of Canada and the adjacent United States using the Fifth Assessment Report of the IPCC. Can Tech Rep Hydrogr Ocean Sci. Fisheries and Oceans Canada

* Zhang Y, Xu Y, Dong W, Cao L, Sparrow M (2006) A future climate scenario of regional changes in extreme climate events over China using the PRECIS climate model. Geophys Res Lett 33:L24702

* Zhao L, Yang F, Milano S, Han T, Walliser EO, Schöne BR (2018) Transgenerational acclimation to seawater acidification in the Manila clam Ruditapes philippinarum: preferential uptake of metabolic carbon. Sci Total Environ 627:95-103

Submitted: December 13, 2018; Accepted: August 22, 2019 Proofs received from author(s): November 21, 2019 